\title{
Moving Earth and Building Monuments at the Carson Mounds Site, Coahoma County, Mississippi
}

\author{
Jayur Madhusudan Mehta, ${ }^{1}$ Kelsey M. Lowe, ${ }^{2,3}$ Rachel Stout-Evans, ${ }^{4}$ and John Connaway \\ ${ }^{1}$ Department of Anthropology, Tulane University, 101 Dinwiddie Hall, 6823 Street, Charles Avenue, New Orleans, LA 70118, USA \\ ${ }^{2}$ School of Geography, Planning, and Environmental Management, University of Queensland, St. Lucia, QLD 4072, Australia \\ ${ }^{3}$ Coastal Environments Incorporated, 812 Water Street, Biloxi, MS 39530, USA \\ ${ }^{4}$ Natural Resources Conservation Service, Metcalfe MLRA Soil Survey Office, 422 Feather Farms Road, Metcalfe, MS 38760, USA \\ ${ }^{5}$ Mississippi Department of Archives and History, Clarksdale Office, P.O. Box 36, Clarksdale, MS 38614, USA
}

Correspondence should be addressed to Jayur Madhusudan Mehta, jmehta@tulane.edu

Received 6 June 2012; Accepted 19 September 2012

Academic Editor: Nicola Masini

Copyright (C) 2012 Jayur Madhusudan Mehta et al. This is an open access article distributed under the Creative Commons Attribution License, which permits unrestricted use, distribution, and reproduction in any medium, provided the original work is properly cited.

\begin{abstract}
The application of combined techniques such as aerial imagery, sediment coring, down-hole magnetic susceptibility, and mechanized trench excavation can provide critical information on landscape formation and mound stratigraphy, specifically if they can be used to understand mound sequences and development. This paper reviews preliminary findings from recent coring and test excavations at the Carson mounds site (22CO505) in Coahoma County, Mississippi. Aerial imagery assisted in the characterization of a crevasse ridge flood deposit underlying the site and detailed field descriptions of the pedology corroborated its existence. Subsequent sediment coring and trench excavation revealed the nature of flooding in prehistory, indicating that high-intensity floods were responsible for the formation of the crevasse ridge and that lower intensity floods were potentially responsible for interruptions in mound building at the site. This suggests that the Carson settlement was initiated on an actively flooding landform. Down-hole magnetic susceptibility correlated effectively with the pedology; however, it also helped discern anthropogenic surfaces (i.e., occupational layers) that are difficult to identify visually, such as those we found in Mound C. Findings from this pilot study demonstrate the utility of sediment coring and magnetic susceptibility as effective and feasible methods for developing hypothesisdriven research.
\end{abstract}

\section{Introduction}

"The problems set by man's nutritive, reproductive, and hygienic needs must be solved. They are solved by the construction of a new, secondary, or artificial environment. This environment, which is neither more nor less than culture itself, has to be permanently reproduced, maintained, and managed." Malinowski 1944:37 [1].

Despite the vast arable potential of the Yazoo Basin in northwestern Mississippi (Figure 1), an area also known as the Mississippi Delta, agricultural activity in the region was greatly limited by unpredictable flooding until extensive levee systems were built in the mid 19th-century [2, page 396]. Before modern engineering projects drained the southern floodplain forests of the basin by preventing seasonal inundations and backwater flooding [3, page 69], the region was a frontier of Native American settlements [4] in an area that has been characterized as an untamed, Edenic wilderness [5, page 42]. We know from the chroniclers of the Hernando de Soto entrada that the Yazoo Basin was a "watery wilderness" [6, page 228], and that the province of Quigualtam in the southern Delta was a "maze of waterways" [7, page 343]. Following criticisms of the romantic perspective that the Americas were a pristine environment prior to European contact $[3,8-11]$ and building on descriptions of the prehistoric Delta environment from the documentary record, our ongoing research investigates environmental adaptations to a dynamic landscape at the Carson mounds site (22CO505 and 22CO518) in the northern Yazoo Basin (Figure 1).

Our environmentally focused research at Carson engages with existing regional archaeological studies [12-15] and 


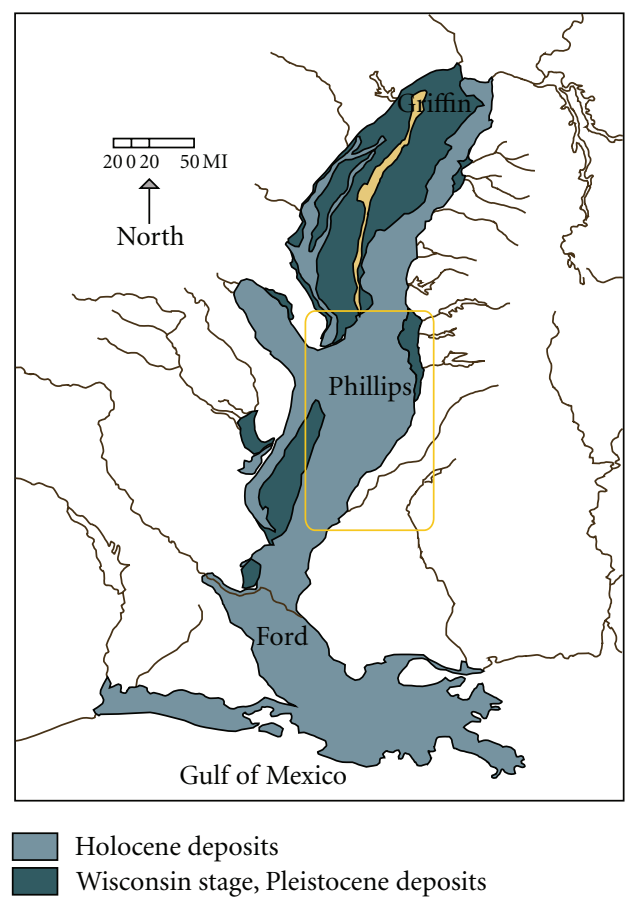

Figure 1: The Lower Mississippi Valley (LMV)—the Yazoo Basin is centrally located in the LMV, in the area enclosed by the yellow box. Phillips, Ford, and Griffin's original survey areas are shown as are deposits predating and postdating the Holocene.

approaches a pan-Eastern Woodlands, late prehistoric cultural complex known as Mississippian through the scientific study of soils, geomorphology, and mound building. Archaeological approaches to Mississippian socio-political complexity have traditionally focused on political economy [16-18] and ideology [19-22] as a means to explain the rapid florescence of large-scale mound building (although mound building takes place during the Late Archaic and Middle Woodland periods, it is not seen at as large a scale as during the Mississippi period [23]), agriculture, and a ubiquitous symbolic religious system [24, 25], [26, page 7], [27] at around. $1100 \mathrm{AD}[12]$. However, in some cases, the environment has also figured significantly into archaeological research evaluating how Mississippian societies adapted their ideologies, settlement patterns, social systems, and political economies to a variety of different environments (e.g., [23, $28,29]$ ). Recently, some researchers have started calling for a reappraisal of older Mississippian models and for the recognition of variation over similarity in Mississippian societies (e.g., the chiefdom concept, [30-34]). Simultaneously, other scholars have recently pointed out that social and political organization cannot be described in toto without considering the dynamic and discursive relationships between humans and their environment $[8,9,35-38]$. Therefore, we propose contributing to the existing works of Mississippian scholars by engaging with an approach rooted in historical ecology, a paradigm influential in the archaeology of Amazonia [36, 39], and we think, quite promising in the archaeology of the Lower Mississippi Valley [10, page 318].

Archaeological studies in historical ecology have in common only their disparate methodologies [40-43]. As defined by Balée, Erickson, and Crumley, historical ecology has four hard-core postulates: (1) nearly all environments have been influenced by human activity, (2) human influence is neutral on biodiversity-humans are not programmed to destroy or to harmonize with nature, (3) different societies have differential effects on world and local environments, and (4) human interaction with the environment should be understood as a global phenomenon $[8,9,39]$. In the Southeast, many have identified with the processual approach and methods grounded in the earth sciences [4451]. While these studies are innovative in their methods, their research has generally focused on how the environment structures society, eliding the notion that humans are also agents of their own destiny. On the other hand, Hammett's $[52,53]$ research on anthropogenic landscapes considers how Indians in the Carolinas actively managed their fields and forests. Making use of travel writings and journals from the early Contact period, Hammett finds descriptions in the literature of blazing fields set afire and of cleared forests used as pastures. Finding evidence of management practices, Hammett claims the Indians of the Carolinas had an informal model of landscaping extending for miles beyond their towns. Clearly the ethnohistoric record has much to contribute to studies of historical ecology, as does the scientific study of soils and ecofacts. Uniting the two perspectives, humanist and positivist, certainly has the potential to yield numerous insights into how Mississippian societies organized subsistence, settlement, and social order.

For example, at the protohistoric Jordan site in Morehouse Parish, LA, evidence of a large-scale water control system designed to capture and store surface runoff has 

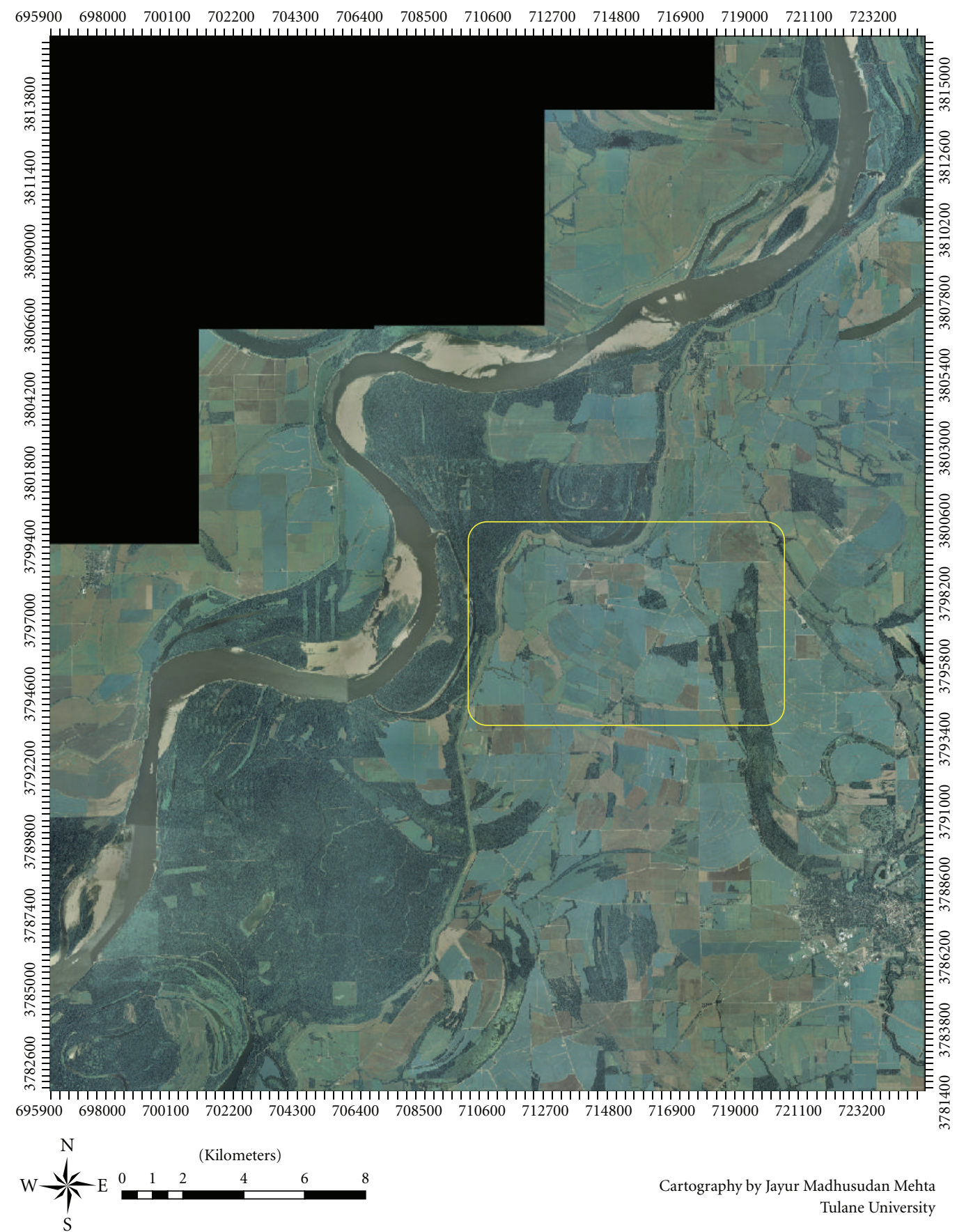

Cartography by Jayur Madhusudan Mehta Tulane University

Figure 2: Upper Yazoo, Mississippi channel scars demonstrate the frequency with which rivers move and landforms evolve-yellow box denotes general site area.

been discovered [54]. Mounds at the Jordan site were built within a partially-filled stream channel to divert water to man-made holding ponds for use during times of drought [54, page 310]. With the right perspective, it is possible to recognize that certain features of the built environment, like mounds, borrow pits, ditches, and berms, may also have had functional as well as symbolic purposes. Thus, by focusing on the reciprocal dynamic between man and the environment [55, page 159] through the study of ethnohistory [53], geomorphology [56], the culturally built landscape [57-59], and soils data [60, page 1], [43, page 3-4], we can ask of the Carson mounds site: what were the needs and organization of a community that built a labor intensive settlement atop a dynamic landscape (Figure 2) prone to recurrent flooding?

Carson is one of the largest of the numerous late prehistoric multi-mound sites in the Mississippi Delta, but like many other mound sites in the Lower Mississippi Valley, it has not been investigated to the same extent that other 


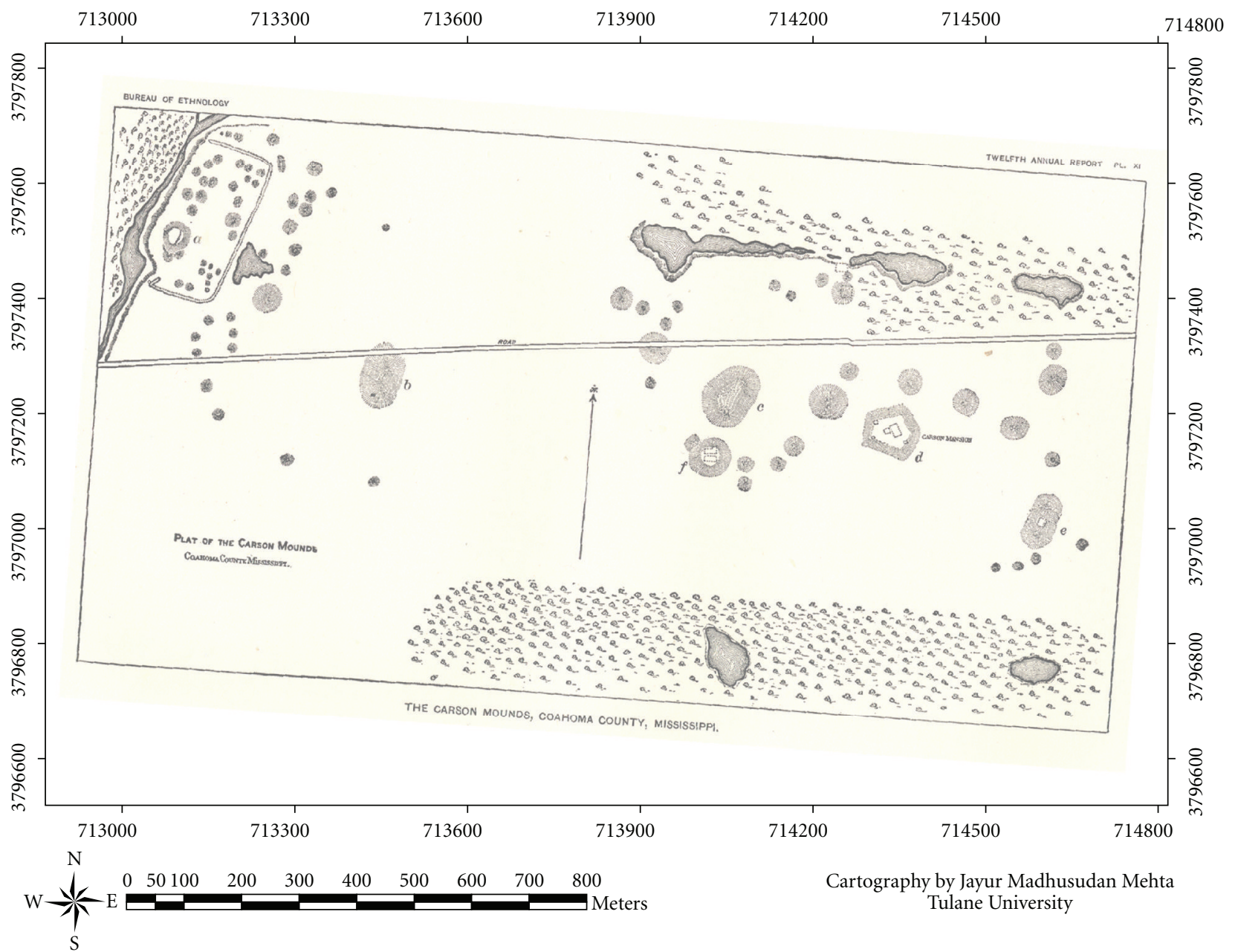

FIgURE 3: Thomas 1894 [68]: Plate XI-Georectified Historic Map of the Carson mounds site in UTM coordinate system, Zone 15N, datum WGS 1984. Mounds labeled A-F are still mostly visible today; the remainder of the smaller mounds have mostly been plowed away, although some low rises are still evident on the landscape today.

Mississippian mound centers like Cahokia [61], Moundville [17, 62, 63], and Etowah [64-67] have been investigated. William Henry Holmes' original map ([68]: Plate XI) of Carson locates 4 large pyramidal mounds, 2 double conical mounds, and presumably over 80 small house mounds covering the expanse of one mile east to west [69, page 5] (Figure 3). While the scale of monumental (large pyramidal and conical) mounds is generally similar to other large Mississippian sites, what makes the Carson mounds unique is the expansive east-to-west distribution of what may potentially be small house mounds (Figures 4 and 5); if so, the site begs a consideration of community (sensu [70]) and site formation processes (sensu [71]). The sheer size of the site also makes it problematic to excavate-as a solution, it was anticipated that modern and efficient forms of investigation, such as remotely sensed data, geophysical survey, soil coring, and mechanical trench excavations, could be used to gather data efficiently, and were therefore used as part of this research.

This research builds upon data derived from ten days of coring and trenching conducted in July of 2009. Sediment data collected from these soil cores revealed possible evidence of a significant flood event contemporaneous with Carson's occupation, suggesting that an active river channel was present adjacent to the site during the period of Mississippian settlement. Specific lines of inquiry that guided the 2009 efforts are as follows.

(1) Where was the Mississippi River during the occupation $(\mathrm{s})$ ?

(2) Was the Carson site built on an active river channel or beside an oxbow lake?

(3) Can sediment coring help discern if indeed Carson is one site or a palimpsest of several?

Data obtained from the 2009 season have permitted some initial impressions on these questions, in particular on the locations of anthropogenic features on the landscape relative to the Mississippi River channel chronology as developed by Fisk [72] and Saucier [73]. 


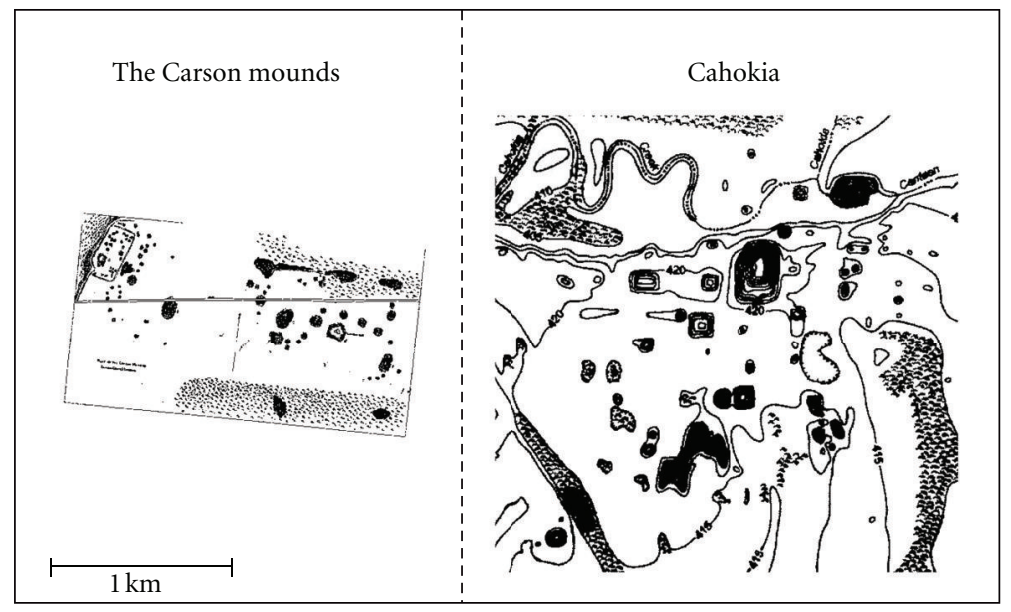

Figure 4: Graphic comparison of the sizes of Cahokia and Carson-both images are at the same scale.

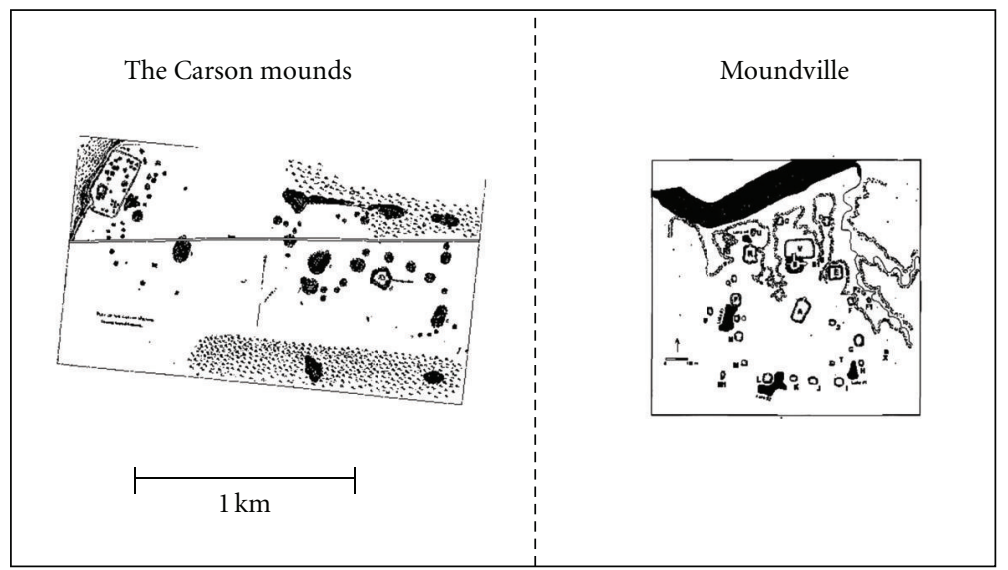

FIGURE 5: Graphic comparison of the sizes of Carson and Moundville-both images are at the same scale.

These efforts have validated an interdisciplinary archaeology rooted in historical ecology and informed methods for use in future excavations.

\section{Archaeological Background of the Yazoo Basin, Mississippi}

Archaeologists have long endeavored to outline major developments in Native American settlement of Mississippi's Yazoo Basin [12, 23, 68, 69, 74-96]. A regional chronology was initially completed by the Lower Mississippi Survey $[13,14]$ in the mid-20th century. Subsequent research has revised old ceramic sequences, providing detailed accounts of material culture and settlement history at sites such as Carson, Anna, Glass, Parchman, and Chittaloosa [97-102]. Although recent scholarship on Mississippian societies has focused on a variety of far-ranging topics (see [30] for a comprehensive review), little emphasis has been given to reconstructing prehistoric environments and the study of how people lived in, adapted to, and altered the landscape in which they lived ([3, page 80$]$; notable exceptions are $[45,54,56-59,73,103,104])$.

Prehistoric settlement in the Yazoo Basin dates from the Paleo-Indian period to European contact. While sites from all known periods have been recorded, based on the numbers of mounds built, the Mississippian occupation is the most extensive (Figure 6). Marked by an increase in mound building, a shift to rectangular house patterns, and the intensification of maize agriculture, small and large Mississippian mound centers dot the entirety of the Mississippi Delta landscape. Interestingly, very few of these sites (with the exception of Walls phase sites near modern-day Memphis) have yielded artifacts associated with the Southeastern Ceremonial Complex, a distinctive symbolic religious system composed of iconography developed in the American Bottom, thought to be the Mississippian homeland [19, 25, 26, 64, 105]. Scholarship on large Mississippian sites throughout the midcontinental and southeastern United States is extensive (e.g., $[19,61,63,106,107])$, yet the large multi-mound centers of the Yazoo Basin have remained largely ignored (excepting $[12,15])$. This project can begin to remedy this discrepancy 


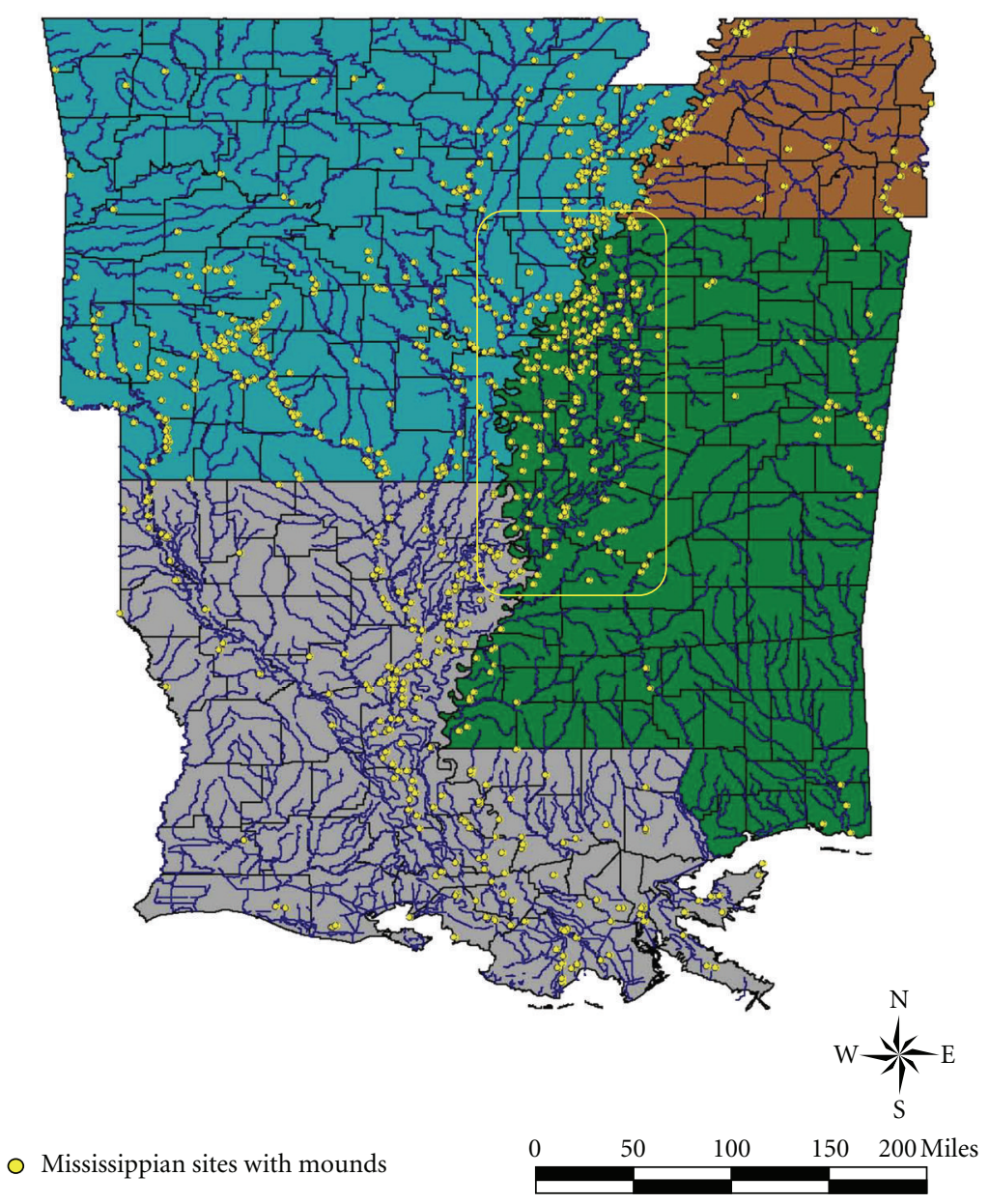

FIGURE 6: Extensive mound construction took place in the LMV during the Mississippi period. Nowhere so was this more evident that in the Yazoo Basin, enclosed by yellow box, where numerous mound centers were constructed from 1200 to 1540 AD. Image adapted from Prentice [112, page 103].

by engaging in theoretically driven research bringing Carson into the forefront with other large Mississippian sites such as Etowah, Moundville, Cahokia, and Spiro.

Some basic descriptions of the Carson site have been published (e.g.) $[14,69,88])$, but excavations identifying specific theoretical issues in anthropological archaeology have only recently begun. Brown [69] noted ceramic evidence from controlled surface collections for Late Woodland and Late Mississippian occupations at the site. Recent work by Lansdell [98] confirms Brown's broad chronology. Test excavations, surface collections, and a reanalysis of Mississippi Department of Archives and History (MDAH) collections by Lansdell demonstrates an occupation spanning from the Late Woodland, based on the presence of Baytown Plain and Mulberry Creek Cordmarked ceramics, to the Late Mississippian and contact periods. Burlington chert and blade core technology at the site further attest the presence of a Mississippian occupation and demonstrate connections between the Carson community with groups from Arkansas and the American Bottom [87, page 204]. While lithic and ceramic data provide a general temporal association for the site, its broad time-span requires further investigation. Additionally, claims that the site was one of the historic Tunica towns, Quiz Quiz, as well as a site visited by the Soto expedition, have yet to be corroborated [108].

Preliminary investigations in the winter of 2008 by John Connaway (MDAH), David Abbot (MDAH) and Jayur Mehta (then with MDAH), revealed a large village and cemetery associated with Mound A, the largest mound documented at Carson (Figure 7). Preliminary radiocarbon dates (Table 1) from a center post-mold from House 8 in the associated village date the western portion of the site near Mound A to $840 \pm 60 \mathrm{BP}$ (cal 1040 to $1280 \mathrm{AD}$ ), squarely within the beginning of the Mississippi period. However, a charcoal fragment extracted from the center of a postmold related to the construction of a stockade post has been dated to $420 \pm 50 \mathrm{BP}$ (cal 1420 to $1530 \mathrm{AD}$ ), suggesting some of the palisade was constructed later in time than House 8. Furthermore, a radiocarbon date from Burial 13 resulted in a much later date of $340 \pm 50 \mathrm{BP}$ (cal 1450 to $1660 \mathrm{AD}$ ). More precise dating of the structures, and certainly the burials, at Carson is needed, particularly due to the rapidity of 


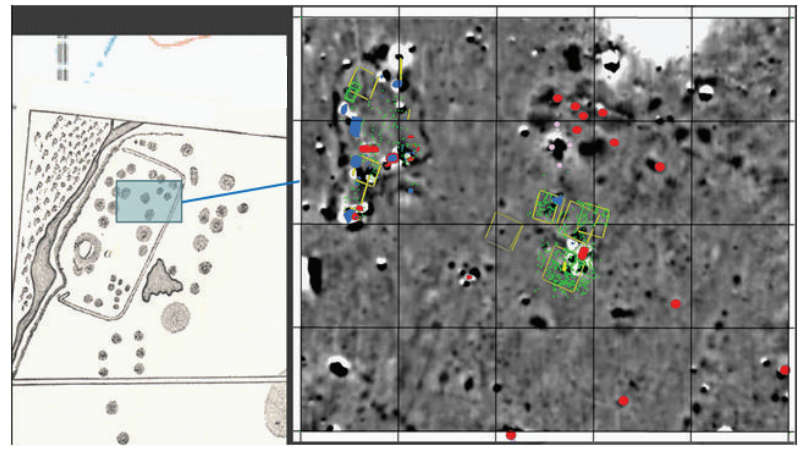

FIgURE 7: University of Mississippi and MDAH excavations at Carson-image at left shows Mound A, small house mounds, and an earthen embankment at Carson. Inset block depicts the outlines of prehistoric structures, postmolds, and pits over gradiometer imagery collected by the University of Mississippi. Images courtesy of Jay K. Johnson.

TABLE 1: Radiocarbon dates from Mound A village area.

\begin{tabular}{lcccc}
\hline Sample & Measured age & $13 / 12 \mathrm{C}$ & Conventional age & 2 Sigma calibration \\
\hline CO518-1 & $420 \pm 50 \mathrm{BP}$ & $-24.9 \%$ & $420 \pm 50 \mathrm{BP}$ & Cal AD 1420 to 1530 \\
CO518-2 & $340 \pm 50 \mathrm{BP}$ & $-25.9 \%$ & $330 \pm 50 \mathrm{BP}$ & Cal AD 1450 to 1660 \\
CO518-3 & $840 \pm 60 \mathrm{BP}$ & $-25.1 \%$ & $840 \pm 60 \mathrm{BP}$ & Cal AD 1040 to 1280 \\
\hline
\end{tabular}

culture change taking place in the Late Mississippi to postContact periods. After discovering this village and cemetery, it was apparent that additional areas at the site warranted further study, including investigations designed to determine whether Carson represents one settlement, or several. To answer this question, we turned to soil coring, remote sensing, and geophysical surveys as appropriate methods of investigation.

\section{Methods}

Subsequent to background research and prior to coring and excavations, remotely sensed imagery was obtained from several sources for visual analysis. Imagery obtained from Google Earth, a free program accessible on most personal computers, enabled us to assess, visually, how the landscape at the Carson mounds site has changed from 1994 to 2007. Multi-spectral imagery from Positive Systems (Airborne Data Acquisition and Registration (ADAR)) was also consulted, as well as imagery from the Shuttle Radar Terrain Mission (SRTM). These data were then used inductively to guide the placement of soil cores around the Carson landscape with the objective of boring a wide variety of surficial landforms.

The Natural Resources Conservation Service (NRCS) provided a truck-mounted Giddings hydraulic soil corer for our soil coring regimen in 2009. Each core was $5.08-\mathrm{cm}$ in diameter, and each core was described in the field following the USDA-NRCS soil guidelines found in the Field Book for Describing and Sampling Soils (version 2.0, National Soil Survey Center, NRCS, USDA, Lincoln, Nebraska) and with Munsell soil color chart designations. Soil cores were bored and extracted on the toe and side slopes and summits of accessible mounds and in the field north of the road transecting the site. In forthcoming field seasons, we plan to excavate cores along regularly defined transects.

Following soil coring, down-hole magnetic susceptibility tests were completed in a number of the bore holes using a geophysical instrument, the Bartington Instruments $\mathrm{MS} 2 \mathrm{H}$ Down-hole Magnetic Susceptibility Meter. Magnetic susceptibility is a measure of the ease with which a material can be magnetized [109, page 25]. This technique developed by Rinita Dalan ([110, page 263], [111]) helps us understand site-formation and post-depositional processes and can be used as follows.

(1) To identify buried sites-on an undifferentiated surface environment where no artifacts are present, the down-hole meter can identify carbonized and anthropogenic soils indicative of prehistoric human activity.

(2) To identify activity areas, features, and cultural layers-relative variation in susceptibility profiles can facilitate prospection and the identification of potential excavation blocks.

(3) To build and correlate stratigraphic sequencesusing susceptibility profiles in conjunction with coring data, we can describe soil horizons across the landscape without large-scale excavation.

Readings were taken by inserting the instrument down the bore hole to a depth of one to two meters. Down-hole readings were processed and analyzed with Microsoft Excel and Surfer mapping programs. 


\section{Results and Discussion}

Several different findings were made possible using the methods described above. Qualitative assessment of the aerial imagery shows Carson is situated on a linear east-west ridge of soils that are at a higher elevation than the soils to the north and south. Based on subsurface stratigraphy from successful coring and trenching, this ridge may potentially be a crevasse splay underlying some of the mounds at Carsonin particular mounds D and C. This deposit may indicate that an active river channel was present here before any mound building occurred. Furthermore, some cores reveal flood sands interrupted the construction of mound C. If that were the case, the Carson site may be contrary to the observed patterning of sites around levee ridges and oxbows in the northern Mississippi Delta (see [81], [101, page 39]) — instead, the sight may have been built adjacent to an actively flowing river. In addition, Fisk [72] also suggested an even older channel once ran near the site (channel 5), however, our preliminary survey could produce no data to corroborate Fisk's placement of the channel (sensu [113]). More recent data on soil development indicates the site is located within Saucier's Hpm stage 1 meander belt, which dates from 3000 B.P. through the present $[73,114]$. The broad time range Saucier proposes for the Hpm-1 meander belt is based on the paucity of evidence to support the detailed ordering of river stages that Fisk proposed initially in 1944-given the frequency with which Mississippi River channels moved, the 5000 year time period for the Hpm-1 meander belt was sufficient enough for channel oscillation to destroy, reclaim, and/or fill and veneer earlier abandoned channels. Saucier cautioned that Fisk may have gone too much into detail based primarily on channel scar signatures, because, he (Saucier) could not find the geomorphic, or soil stratigraphic evidence to support such detailed ordering of channel stages. It may be likely an earlier channel was there, but evidence of the channel and its banks have likely been destroyed, filled in, or covered over by later channels so completely and to such a depth that it is possible our equipment could not bore to a sufficient depth to detect the earlier channel. Therefore, the depth of the channel Fisk [72] proposed may indeed lie well below the capabilities of the Giddings coring device in use, and consequently, we cannot entirely discount the possibility of its existence.

\subsection{Sediment Coring and Magnetic Susceptibility Data}

4.1.1. Mound A. Mound A is a truncated pyramidal mound located at the far-western margin of the Carson site adjacent to Fisk's relict channel 11 [72]. In 2009, cores 13 and 22 were excavated on Mound A with the goals of identifying the prehistoric ground surface as well as clarifying some aspects of its construction chronology. Mound A is 4.2 meters tall, and at its broadest dimensions at the base is $67.2 \mathrm{~m}$ by $51.4 \mathrm{~m}$; currently a burned out modern structure sits atop the summit.

Core 13 was bored on the west facing side slope of Mound A, 14.4 meters east from Riche's Bayou (Figure 8). Riche's Bayou is an extinct channel of the Mississippi
River, Fisk's channel 11. It is also the same channel on which another large Mississippian site, Parchman, is situated [115]. Approximately $79 \mathrm{~cm}$ of mound fill was cored before encountering a thick midden of daub and charcoal in the mound fill, which extended to $117 \mathrm{~cm}$ below surface (bs). Because of soil compaction, a common problem in soil coring $[116,117]$, the midden encountered in the core at $79 \mathrm{cmbs}$ is probably the peak in magnetic susceptibility shown in the $2 \mathrm{Ab} 1$ strata, a buried $\mathrm{A}(\mathrm{Ab})$ or surface horizon (see Figure 10). The first peak in susceptibility just before $40 \mathrm{cmbs}$ may be a result of daub or charcoal inclusions in the core hole as no buried surface was detected. These peaks have been seen at similar site settings in the region [116]. Brown, very fine sandy loam (natural levee soil) was observed below the midden. This layer appears to be part of mound fill because at $158 \mathrm{cmbs}$, a distinct ash lens was encountered (Figure 9). This could indicate the area around the mound was burned of vegetation before construction started or that perhaps we hit a hearth or just hit some hearth scrapings. The ash lens at $158 \mathrm{cmbs}$ (right above the 2Ab3 horizon) was weakly magnetic, likely due to the complete oxidation of organics. The strong magnetic peak at $165 \mathrm{cmbs}$ and below the ash lens coincides with the likely pre-mound surface before Mound A was constructed. Another moderate peak at $220 \mathrm{cmbs}$ in the $3 \mathrm{Ab}$ stratum suggests a buried surface horizon below natural levee soils, revealing that Mound A was built over a levee surface that was occupied, flooded over, and then reoccupied. These buried surfaces appear to be remnants of natural levees that existed in the locale prior to Mound A, and given their magnetic peaks, they may have been occupied or cleared of brush with fire before the mound was built. Sandy loams are present below these buried natural levees until about $447 \mathrm{cmbs}$, after which a grayish brown silty clay slackwater deposit shows up. This clay deposit, which is much different from the previous layers, was deposited from a distant channel before the present one migrated to its charted position.

Core 22 was located directly on top of Mound A (Figure 8) and it revealed the mound was made in at least two large construction stages. Evidence of a buried A horizon was found in the core at 221-263 cmbs-this horizon likely represents the end of the first mound building stage. Another buried A horizon was found at roughly 4.5 meters below surface. Interestingly, gleyed soils indicative of channel fill were encountered about 1 meter bs. These water logged deposits may have come from Fisk's extinct channel 11 or from another abandoned channel. From 550 to $670 \mathrm{cmbs}$ a brown, structureless, very fine sandy loam similar to natural levee or flood deposits was encountered but we could not excavate deep enough to identify the surface horizon buried in the natural levee that we detected in core 13. No downhole magnetic susceptibility readings were taken in this bore hole due to time and budgetary constraints.

Given that the landform on which mound A is situated was at one time a natural levee for Fisk's channel 11, it is not surprising such sandy soils were detected. It is worthwhile to note that when standing in the bottom of the channel scar, Mound A looks almost twice as large-this strategy in mound construction is reminiscent of some mounds in 


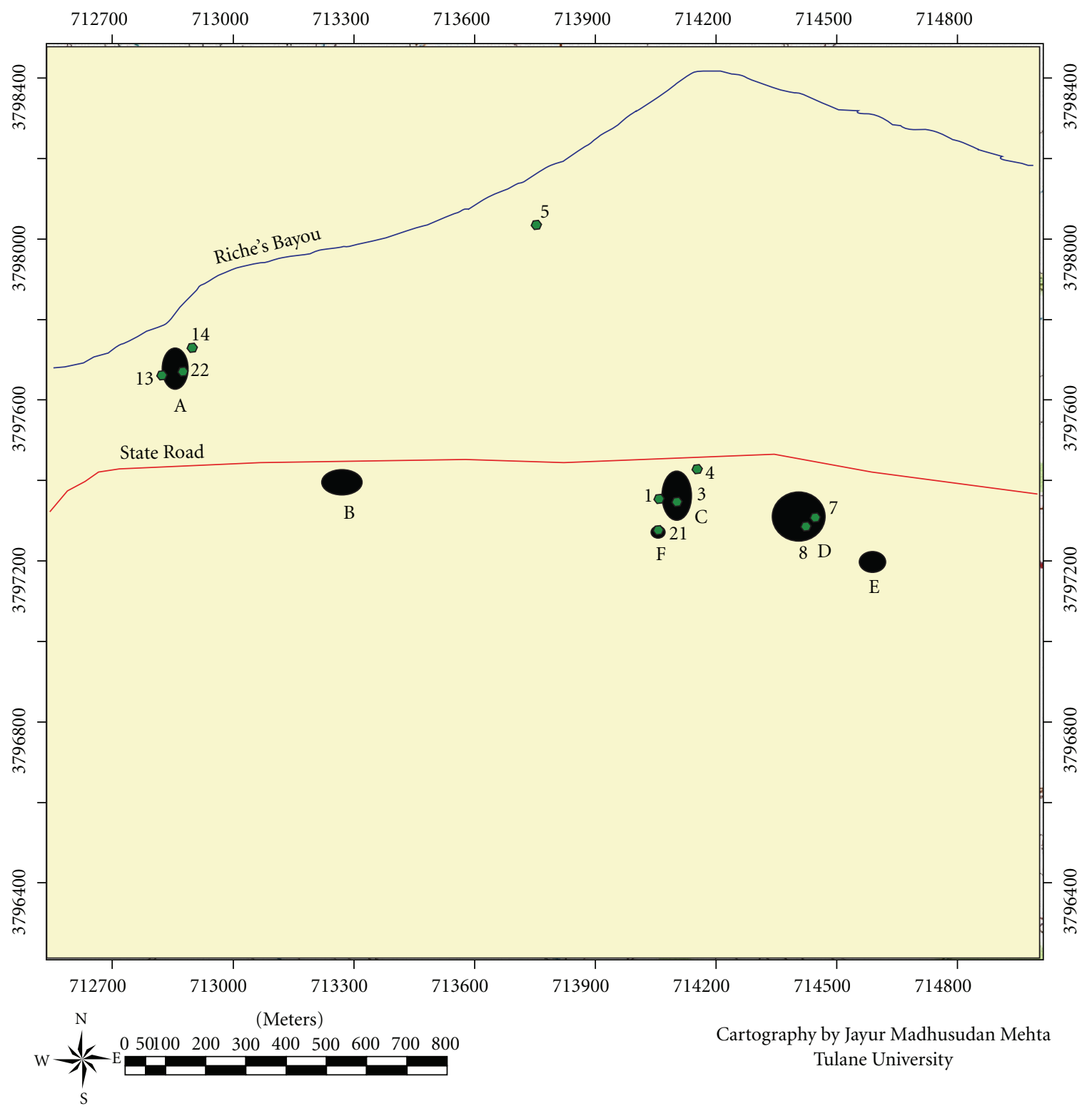

Figure 8: Modern schematic map of the Carson Mounds showing locations of large mounds still evident on the landscape and bore holes excavated in 2009 (green dots).

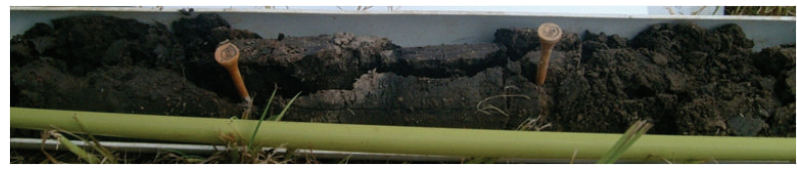

FIgURE 9: A distinct ash lens encountered in core 13, 158-162 cmbs, Mound A. This ash lens was in low magnetic susceptibility likely due to the complete oxidation of organics in the sediment. The ash lens may be from a burning event prior to mound construction or perhaps originated from hearth scrapings.

the Natchez Bluffs that similarly make use of the natural topography, such as Anna and Emerald [23]. Furthermore, at the nearby sites of Parchman and Salomon, the principal mounds are both similar in that they appear much larger from the channel bed than from the surrounding landscape.
A survey of other mounds in the area may potentially reveal this to be a common trend in construction.

4.1.2. Mound C. Mound C is centrally located at Carson, and like Mound $\mathrm{A}$, it has an abandoned and modern structure 


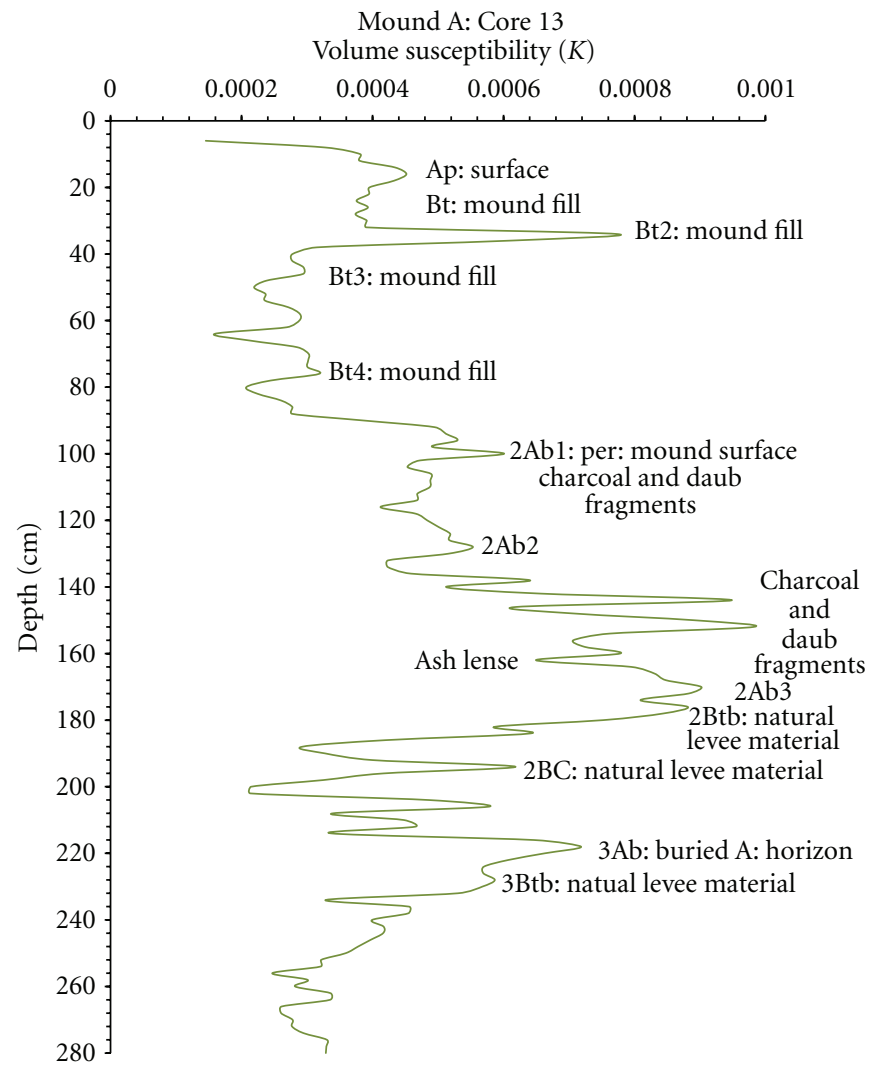

Figure 10: Volume susceptibility graph for core 13. Highly organic horizons consistently have strong peaks (Ap, 2Ab1, 2Ab3, 3Ab), as do some instances of mound fill where daub and other burned materials were encountered.

atop its summit. In 2009, cores 2, 3, and 4 were excavated on the flank and summit, and a backhoe trench was excavated along the western flank. Only core 2 was probed with the down-hole susceptibility meter. Currently the mound is shaped like a truncated pyramid and it is $2.3 \mathrm{~m}$ tall with maximum dimensions of $105.6 \mathrm{~m}$ by $68.6 \mathrm{~m}$.

Core 3 was taken at the mound summit (Figure 8 ). The upper stratum contained mound fill extending to $248 \mathrm{cmbs}$. Below the upper strata, a buried natural surface, an A Horizon, was detected. This buried natural surface is a very dark gray (10YR $3 / 1)$ silty clay ( $45 \%$ clay) and it has an abrupt boundary with the mound fill above it. This natural surface is approximately 30 centimeters thick. Below it are 200 centimeters of fine, fine-silty, and fine-loamy material interbedded with buried organics (oak leaves and fibers) and some free water. Some of the fine-silty layers appear similar to the back end of natural levee deposition. At 388 centimeters, there is a 6-centimeter layer of very dark grayish brown (10YR 3/2) silt loam, which is evidence of another buried natural surface. There are some organic materials (possibly thatch) buried in this horizon, as well as a small number of chert flakes. Beneath this second buried natural surface there is a sequence of fine-loamy and fine-silty layers that appear similar to fine-loamy natural levee deposition-the core terminates at 478 centimeters below surface.
Core 4 was completed on the north side of the mound (Figure 8), in an area facing the ridge and swale topography of a remnant channel. There is no evidence of mound building in this core and it appears to contain natural stratigraphy indicative of alluvial deposits. From the ground surface down to $240 \mathrm{~cm}$ is an alternating sequence of brown and dark yellowish brown fine-loamy and fine-silty material, suggesting natural levee deposition from frequent inundation and flooding. Beneath these layers are stratified layers of finesilt and fine sand, with moisture increasing with depth. At $470 \mathrm{~cm}$, there is a layer of gleyed clayey material with shiny pedogenic facies designated as Bgss, indicating slackwater deposition. The water table is encountered at $500 \mathrm{cmbs}$ along with a grayish brown fine-loam. At 530 centimeters, there continues to be free water and a gleyed, coarse grained sand that could be either a point bar, front slope and summit natural levee deposits, or crevasse deposits.

The trench through Mound $\mathrm{C}$ begins on the west edge of the summit/shoulder slope of the mound and continues west down the backslope, footslope, and toe slope (Figure 11). The trench was approximately half a meter wide and ten meters long. At the foot slope position there were approximately $120 \mathrm{~cm}$ of mound fill. From 120 to $139 \mathrm{cmbs}$, there was a brown, very fine sandy loam natural levee deposit, interpreted as a flood event as it appears that this layer 


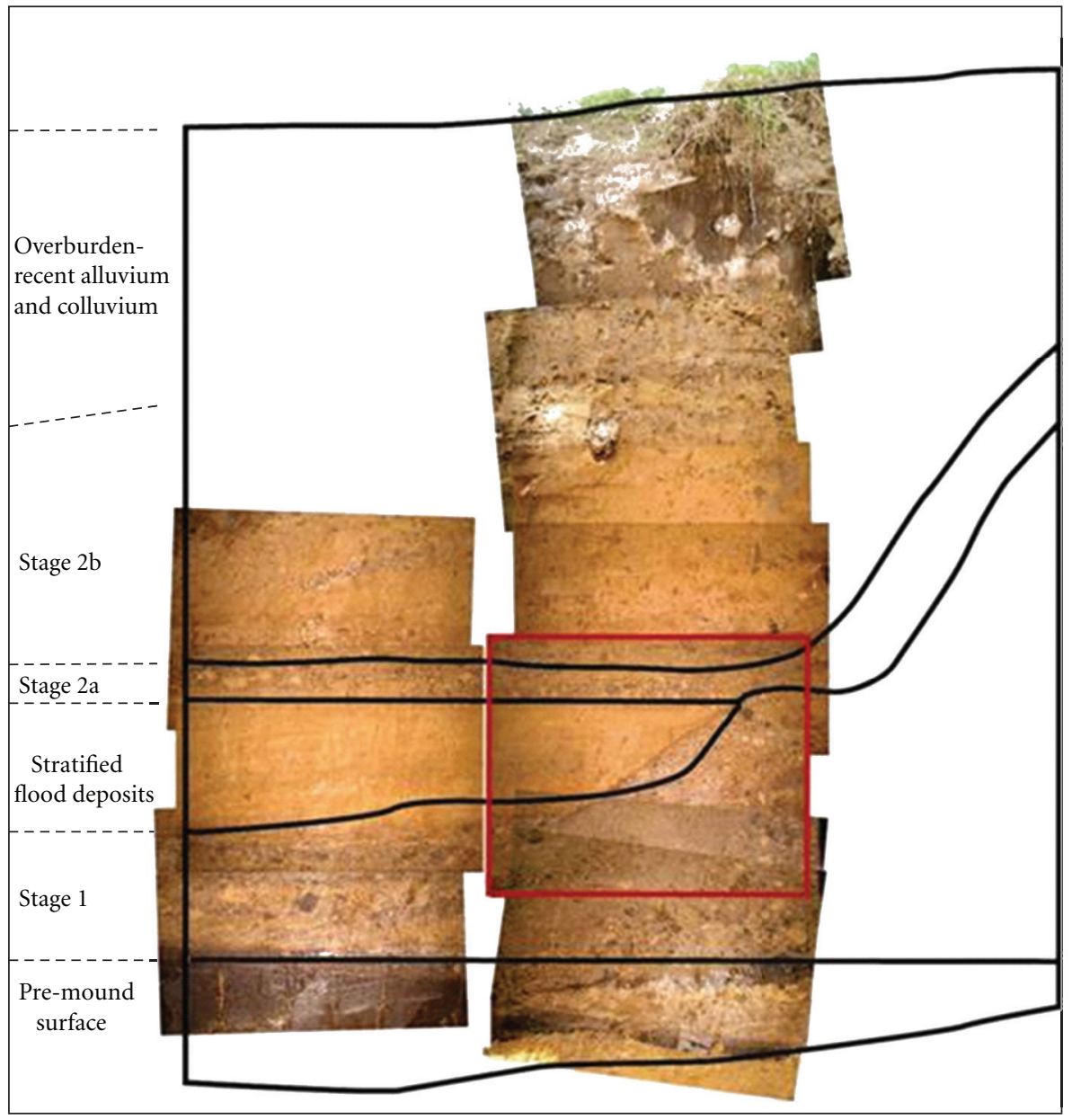

FIgURE 11: Photo-mosaic trench profile of Mound C. The red box encloses the interface between mound stage 1, flood deposits, and the overlying stage 2 . Image courtesy of Jay K. Johnson. Scale and direction of photos unknown.

washed over some portion of the construction of this mound. Below this flood deposit was another layer of mound fill that extended to about $155 \mathrm{cmbs}$. A buried horizon was detected from 155 to $171 \mathrm{cmbs}$, and, underneath this buried horizon, was fine, grayish brown, backswamp clay.

Core 2 was a sediment core bored and extracted close to the summit position of the mound on the shoulder slope (Figure 8). From the surface, mound fill continues to $285 \mathrm{cmbs}$, at which point a very dark grayish brown (10YR $3 / 2$ ) silty clay loam ( $38 \%$ clay) buried natural surface appears). Core 2 magnetic susceptibility readings (Figure 12) show the original surface layer, followed by a thick layer of mound fill that extends to $100 \mathrm{cmbs}$. A few peaks are present in the mound fill and may be related to small daub and charcoal inclusions often found in mound fill. Around $100 \mathrm{cmbs}$, a strong peak in susceptibility was observed and could indicate a natural or anthropogenic surface. The peak at $100 \mathrm{cmbs}$ in the magnetic susceptibility data is not consistent with the sedimentology data as no visible buried layer was observed in the core, only mound fill. Given the utility of this instrument for detecting anthropogenic disturbances in undifferentiated soil $[110,111]$, this peak may indicate a buried surface horizon, perhaps at a time when moundbuilding ceased to allow for short term occupation. This occupation may not have left visually detectable remains in the soil but could have impacted the soil enough for it to be detected using magnetic susceptibility — we will have to test for this short-term occupation in future excavations. There is a clear smooth boundary between the buried natural surface and the mound fill horizon above it. The natural surface horizon is approximately 33 centimeters thick, with 30 centimeters of fine-silty material lying beneath it. The core ends at 348 centimeters below surface. Based on sediment data, we might suggest that although Mound $\mathrm{C}$ was built rather quickly in the earlier stages, later construction proceeded at a slower rate allowing people to occupy the mound for some time, perhaps for a generation at a time, before additional fill was placed atop the mound, in much the same way that typical Mississippian platform mounds at smaller sites were built gradually [118].

4.1.3. Mound D. By sheer volume, Mound D is the largest earthen monument at Carson. With a volume of 11 , $665.2 \mathrm{~m}^{3}$, it has double the volume of the next largest mound, 


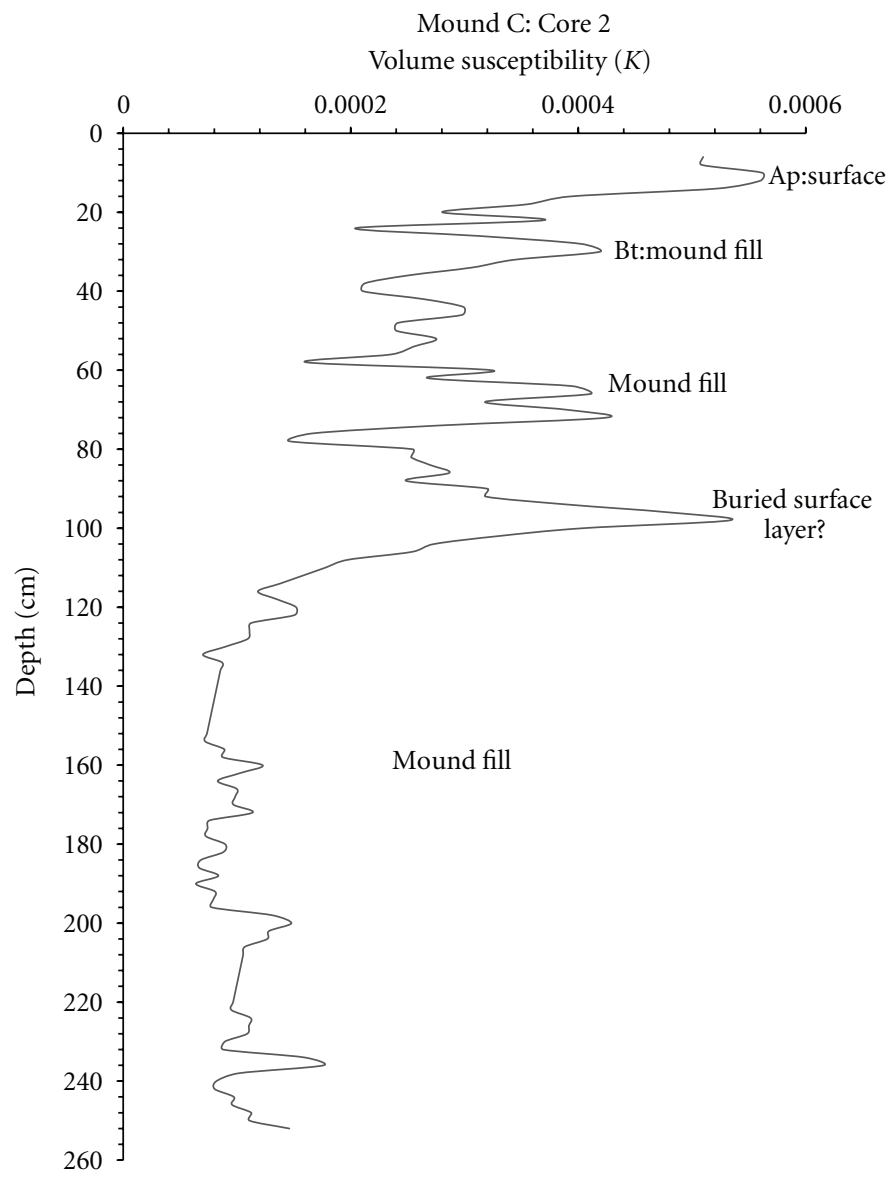

FIGURE 12: Volume susceptibility graph for core 2. The strongest peak in the graph occurred at a lithostratigraphic horizon that was not ascertained to be anthropogenic, but rather ubiquitous mound fill. This peak may point to the utility of the device for identifying anthropogenic sediments in undifferentiated fill.

Mound A. Like mounds A and C, Mound D once had a modern structure on its summit, although now all that remains is a cistern, a possible cellar, and some brick footings. Currently Mound D, five-sided in plan, is $4.5 \mathrm{~m}$ in height and its maximum dimensions at the base are $91.7 \mathrm{~m}$ by $77.6 \mathrm{~m}$. Core 7 was excavated on the summit in 2009 and was taken directly to the prehistoric ground surface.

Core 7 (Figure 8) exhibited 18 different horizons, of which there are possibly four different mound surfaces. These mound surfaces were also noted in down-hole magnetic susceptibility (Figure 13). In this core, the layer of soil below the A-Horizon appears to be highly weathered, and it has a light tan color, possibly representative of slope wash or a weathered exterior surface. Below this is a rich organic layer, showing the third mound surface which shows a weaker magnetic signal in the susceptibility data. This weaker signal may be related to a shorter occupation during this third mound stage. About $50 \mathrm{cmbs}$, another rich organic layer designated as the second mound surface was encountered, followed by a thick layer of mound fill. The second mound surface is more visible in the susceptibility data suggesting a longer occupation span for stage 2 s construction. Around $227 \mathrm{cmbs}$, another thin organic layer was detected, designated as the first mound surface, which was followed by a thin layer of mound fill. This shows up as weakly magnetic and could be a result again of a shorter occupation for mound stage 1, or result in the loss or translocation of organic materials. A rich buried A Horizon was observed from 247 to $265 \mathrm{cmbs}$. This buried layer also contained a weak magnetic signal and could be a result of weathering of organics. Underneath this fourth buried horizon are natural soils similar to those around and below Mounds A and B, suggesting that initial construction at Mound D took place sometime after the nearby backswamp was covered over with crevasse materials, making Mound D more recent than Mound C, which has crevasse material overlying the flank of the mound.

4.2. Interpretation of Sedimentology. The Carson mounds is located on what the NRCS defined for this area as the Bosket and Dubbs soil series, very fine sandy loam surface texture, with $0-2 \%$ slopes. These are well-drained to moderately welldrained, fine loamy to fine silty textured soils that occur on old natural levees and ridges. Surrounding soils are found on backswamp areas and ridge and swale topography. The site is situated on top of a small terrace or elevation break, surrounded by ridge and swale topography (Figure 14). Data 


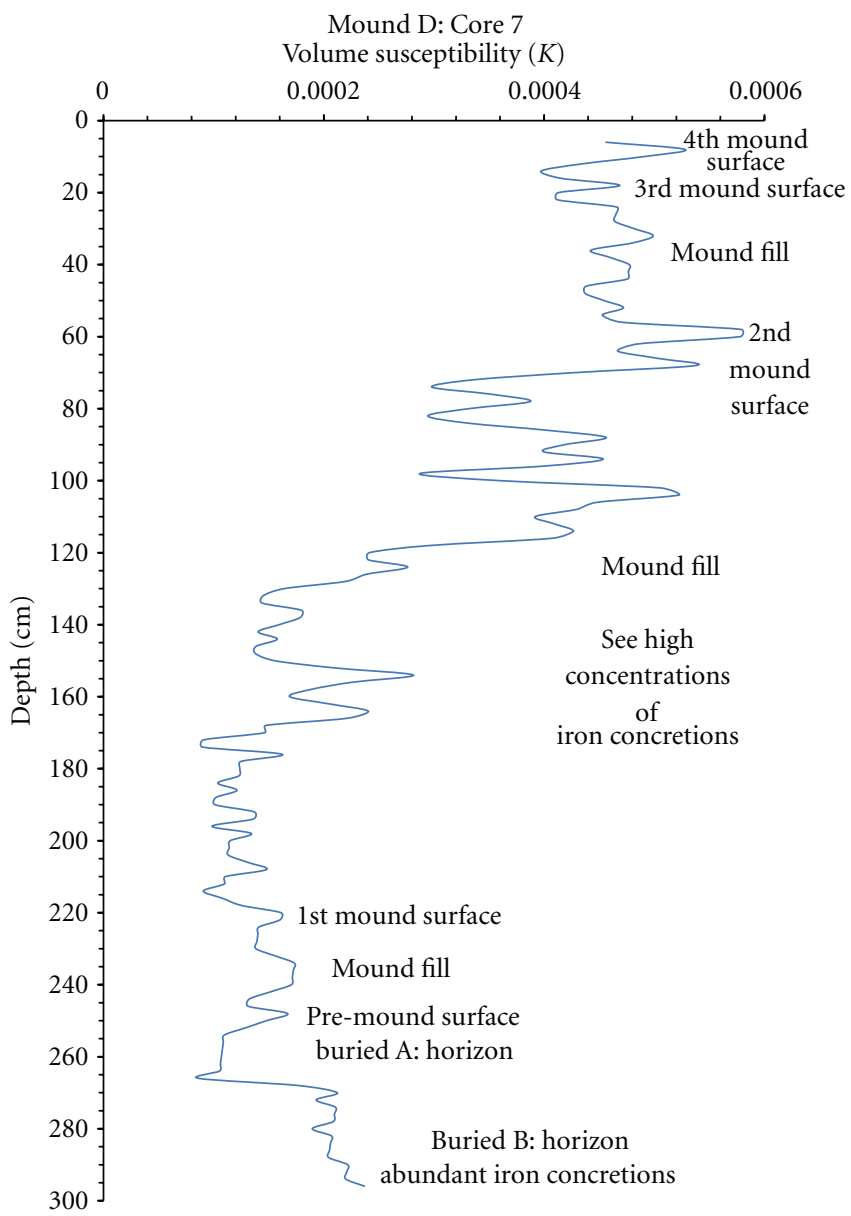

Figure 13: Volume susceptibility graph for core 7, Mound D. As in core 2, there is at least one strong peak in undifferentiated mound fill. Interestingly, both the pre-mound surface and the top of the first mound stage have very low susceptibility values. These low values are likely a result of natural weathering processes (leaching of organics), although the intensity of occupation (less contribution of magnetic material on the surface or perhaps reduced burning) and the actual mound fill itself, which may contain weaker magnetic minerals than those found later, could also explain these lower values.

from the soil cores suggest this elevation break originated from a crevasse splay emanating from Fisk's channel 11 that likely occurred sometime before mound construction, although this conclusion is still tentative. This crevasse event which built up the linear ridge may totally predate all of Mound C's construction or simply predate some phase of its construction. This linear ridge could be the base for the elongated arrangement of mound construction; a future study should be directed at evaluating the relationships between archaeological and geomorphic landforms. Currently, it is the opinion of the authors that most Mississippian sites in the Yazoo Basin are found on curved natural levees lining oxbow lakes, a typical and common landform in the region, thereby making Carson's location on a crevasse splay somewhat unique. In particular, it appears the elongated arrangement of mounds at Carson was predicated to some degree by the formation of a crevasse ridge.

The sand layer found in our trench on Mound C results from a flood event, but it is unlikely that is represents a high-intensity crevasse, which would leave greater erosional evidence and disturbances behind. This layer, approximately 20 centimeters thick, includes brown (10YR 4/3 and 10YR $5 / 3)$ very fine sandy loam ( $<18 \%$ clay). It has very weak fine subangular blocky structure (almost structureless, or massive). Redoximorphic features (iron depletions and iron concentrations) were present but faint. Within this layer were thinner lenses of coarser sand that showed faint evidence of wave or water action. The flood event layer was sitting on approximately 20 centimeters of mound fill (at the sample point). This flood event layer came up to and stopped at the side slope of the mound that had already been built up (Figure 11).

The very fine sandy loam layers found in the trench on Mound $\mathrm{C}$ and in several cores lead us to conclude that Mound C was affected by flooding at some point during its construction history. These flood layers are visible on the side slope of Mound C. After this flood, another stage of construction began. Given these sandy soils at Mound C, one might ask if they are prevalent in other cores across the site- the answer is yes. These flood sediments were evident 


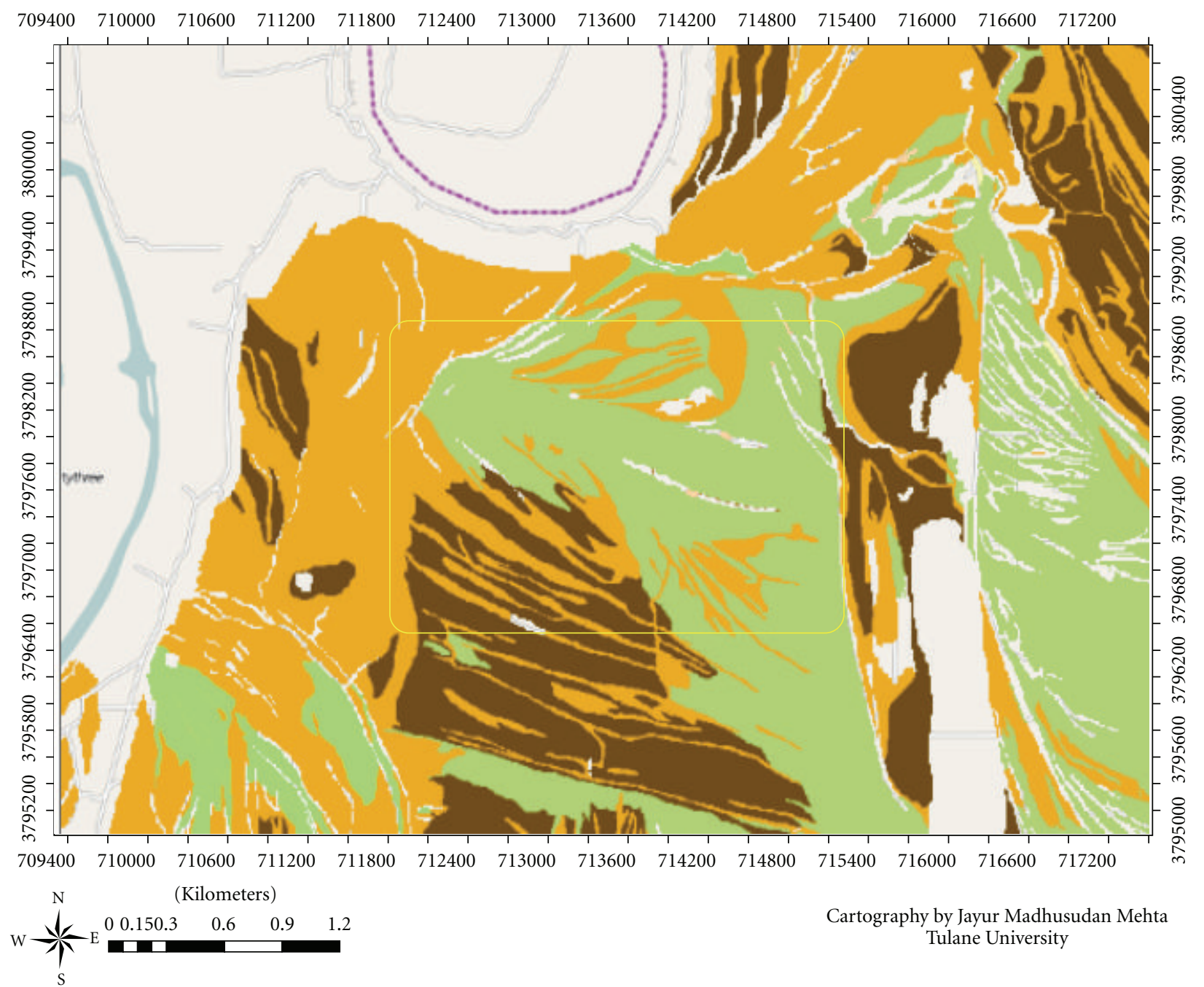

Figure 14: The Carson site location enclosed by yellow box-note surrounding ridge and swale soil delineations-the site itself is built along a linear ridge of younger soils. The light green soils are fine-loamy and fine-silty, mixed alfisols. The brown soils are very-fine, smectitic vertisols, and the orange soils range from coarse-loamy, mixed inceptisols to very-fine, smectitic inceptisols (USDA NRCS Soil Series; http://www.arcgis.com/).

in many other cores $(2,3,4,5,13,14,19,22,25,26-$ Table 2 and Figure 15) - essentially over much of the site. They ranged in thickness from 19 to $140 \mathrm{~cm}$ 's and in depth below surface from $139 \mathrm{cmbs}$ to $317 \mathrm{cmbs}$, indicating flooddeposited soils cover much of the landform on which the site is constructed. We believe it likely that flood-borne soils built a linear-ridge from east to west over one-mile long, and it is on this ridge that the Carson mounds were built. It is unclear how long the crevasse ridge was left to settle before occupations began; future directives should evaluate through optically stimulated luminescence (OSL) discrepancies in the age of sediments deposited at the end of crevasse formation and the beginning of anthropogenic mound building. To some degree, flooding likely continued for some time but at much lesser intensities than that which built the crevasse ridge.

Core 4 was taken from the toe slope of Mound C on natural, relatively undisturbed ground. It is mapped in the
USDA-NRCS Coahoma County Soil Surveyas natural levee soil. At $69-183$ centimeters below surface, there is a brown very sandy loam layer with very weak structure $(\mathrm{Bt} 3$ and BC1 horizons). This layer has approximately $20 \%$ grayish brown masses of redoximorphic depletions and 10\% dark yellowish brown masses of redoximorphic concentrations. The presence of redoximorphic features in the soil indicates a frequent wetting and drying of the soil-frequent wetting and drying episodes result in the reduction and oxidation of iron and manganese compounds, leaving a characteristic mottled appearance to the soil [119, page 158]. Flood-borne sediments would display such features.

Core 5 was taken on a ridge (on the old ridge and swale landscape) in the bare-ground field north of the farm shop. The ground has been disturbed by farming, but has not been significantly land leveled. At 45 to 120 centimeters below surface, there are two horizons, the first at 45-100 centimeters (Bt2 horizon), the second, 100-120 centimeters 


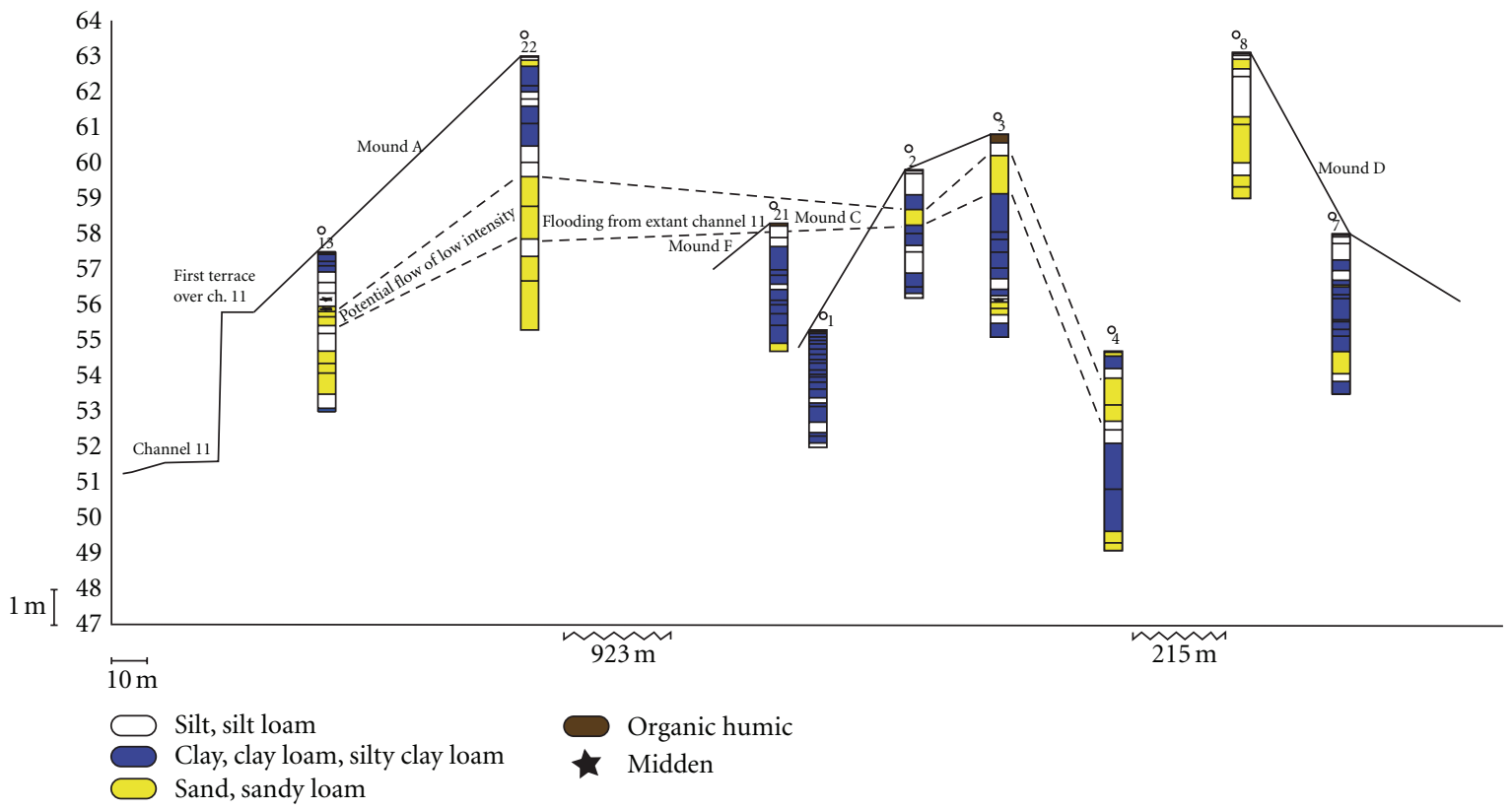

FIGURE 15: Core profiles and the stratigraphic position of some lower intensity flood events (low energy crevasse splays) across the Carson site demonstrate how flooding interrupted mound building at the site. The crevasse that formed the linear east to west ridge that underlies the whole site is deeper than can be shown in the image.

TABLE 2: Excavated cores and depths of potential crevasse or flood sands.

\begin{tabular}{lccc}
\hline Core & Depth $(\mathrm{cmbs})$ & Thickness $(\mathrm{cm})$ & Landscape \\
\hline 4 & $69-83$ & 114 & Level natural ground \\
13 & $317-410$ & 93 & Side slope of mound \\
14 & $87-227$ & 140 & 0 to $1 \%$ slopes, natural ground \\
19 & $54-180$ & 126 & 0 to 1\% slopes, natural ground \\
24 & $53-156$ & 103 & Land-leveled, natural ground \\
25 & $228-346$ & 118 & Toe-slope of mound \\
26 & $126-209$ & 83 & Toe-slope of mound \\
27 & $95-223$ & 128 & Toe-slope of mound \\
Trench & $120-139$ & 19 & Side and toe-slope of mound \\
\hline
\end{tabular}

(Bt3 horizon), that correspond to natural levee deposition and possibly the flood event associated with the layer at Mound C. Bt2 layer is a structureless, yellowish brown very fine sandy loam (18\% clay) that has about $10 \%$ dark grayish brown masses of redoximorphic depletions and 10\% brown redoximorphic concentrations. Bt 3 layer is a structureless, brown very fine sandy loam ( $<18 \%$ clay) that has about $30 \%$ dark grayish brown (10YR 4/2) masses of redoximorphic depletions and $10 \%$ dark yellowish brown masses of redoximorphic concentrations.

Core 14 was taken past the toe slope of Mound A on natural ground before the boundary to the leveled field. At 87 to 227 centimeters below surface, there are two horizons that correspond to the flood event layer in Mound $\mathrm{C}$ trench. The first, at 87-115 centimeters (BC horizon), and the second, 115-227 centimeters (C1 horizon), are brown and brownish gray very fine sandy loam layers. The $\mathrm{BC}$ horizon is a brown very fine sandy loam (18\% clay) with about $10 \%$ dark yellowish brown masses of redox concentrations and weak fine subangular structure. The $\mathrm{C}$ horizons are brown to brownish gray very fine sandy loams ( $10 \%$ clay) with about $20 \%$ grayish brown masses of redox depletions, and no structure at all (massive).

Core 19 was taken in the middle of the pecan orchard south of Mound A on a natural levee landscape. Similar to Core 14 , at 54 to 180 centimeters below surface, there are two horizons that appear to be similar to the flood event layer in the Mound C trench. At 54-105 centimeters, there is a brown very fine sandy loam ( $<18 \%$ clay) that has very weak structure. It has about $20 \%$ dark grayish brown masses 
of redox depletions in it. The second horizon, at 105-180 centimeters, is a brown very fine sandy loam ( $<18 \%$ clay) with no structure (massive). It has about $20 \%$ grayish brown masses of redox depletions in it. Also, 1\% charcoal fragments were found scattered throughout the horizon.

From approximately 50 centimeters to 200 centimeters below surface on the cores taken on natural ground away from the mounds (Cores 4, 5, 14, and 19), there are thick layers of coarse-loamy deposition that would indicate a natural levee sequence or flood event. In comparison to the trench at Mound $\mathrm{C}$, it is difficult to pinpoint a specific corresponding flood event in these core samples. The coarse-loamy layer in the trench occurs at approximately 120 centimeters below surface at the lower end of the trench (coming off the mound). The depths of the coarse-loamy layers on the landscape do correspond to each other. However, the coarseloamy layers in the cores are much thicker (ranging from 93 to 180 centimeters thick) compared to the 20- to 50centimeter thick layer in the trench. This is possible for several reasons: (1) the coarse-loamy layers could be from different flood events and different channels that are carrying similar sediment loads. (2) If it is the same flood event, the deposition could be coming from two different active channels in the area. (3) If it is the same flood event, and there is only one active channel, then distance from the channel and topographic relief may be the influence. As discussed with core 4 , there is a natural levee in front of the trench on Mound C. The difference in topography may account for the coarse-loamy layer being thinner behind (or on the downslope) the natural levee near the trench.

Because of the ubiquity of these flood sediments, there is the possibility the residents of Carson chose to live on an actively flowing, meandering, and seasonally flooding channel of the Mississippi River (c.f. [10, page 314]). Based on how Carson is situated on the land, the findings presented here suggest two possible scenarios. In one, the flood event could have been a massive, singular event that dumped an enormous amount of sediment over the site and its surrounding landscape. Alternatively, a succession of smaller floods from an active channel and various tributary channels could have resulted in the deposition of flood-borne sediments. Determining which of these two scenarios was actually the case in prehistory will require additional coring and fieldwork. What these two scenarios suggest, however, is that cultural adaptations were necessary to live in an actively flooding environment. Given the parameters outlined by Lewis [120, page 39], that sites can (a) be built on locations where flooding is not an issue, (b) that they can incorporate flood-proof features into the design of dwellings, or (c) that they can construct canals and levees at sites to change local flood patterns, and at least three Mississippian sites in the northern Delta, Wilsford, Hays, and likely Carson, all had structures with flood-proof dwellings ([81], personal communication 2012), it is worthwhile to engage in future fieldwork to determine how the residents of Carson adapted to their dynamic environment. Lewis' third scenario adopts a historical ecological perspective, positing that not only can humans adapt but they can also modify their landscape and environment to mitigate flood events.

\section{Conclusions}

Sediment coring and down-hole magnetic susceptibility were found to be incredibly effective tools for evaluating subsurface geology and mound building. Sediment coring has been used effectively for geoarchaeological research $[54,56$, 117] and at Carson it has helped delineate the subsurface geology of the Carson landform that was identified using aerial imagery and surface soil maps. The lithology of the linear ridge that underlies the site has tentatively been defined as a crevasse splay using sediment coring and further tests will need to be conducted in the future to corroborate our initial findings.

Sediment coring also helped define methods of mound construction, especially when used in conjunction with the down-hole magnetic susceptibility meter. Evidence from sediment cores excavated on mound A (cores 13 and 22) suggest the mound was constructed in at least two large stages and that the area on which the mound was built was previously occupied for some time. The $2 \mathrm{Ab} 3$ horizon in core 13 which pedologically appeared to be the pre-mound surface was corroborated by a strong magnetic signal in the downhole susceptibility meter. Another buried stratum below the $2 \mathrm{Ab} 3$ horizon, the $3 \mathrm{Ab}$ horizon, indicates the area under the mound was occupied for some time, flooded over, and then reoccupied. Strong peaks in the magnetic susceptibility of the $3 \mathrm{Ab}$ soils corroborate our pedological assessment that the $3 \mathrm{Ab}$ horizon was likely a buried and inhabited surface.

From core 2 at mound C, only one strong peak in susceptibility ( $100 \mathrm{cmbs}$ ) was detected and it could not be corroborated by our sedimentology data. In the sediment core, no visible buried anthropogenic layer or any soil that would give a high reading was observed. Given the instrument was designed for detecting anthropogenic disturbances in undifferentiated soil $[110,111]$, this peak may indicate a buried surface horizon when mound-building ceased to allow for short term occupation. We think it likely that the short-term occupation did not leave visually detectable remains in the soil but it did change the soil enough to be detected using magnetic susceptibility-future excavations will attempt to reach this horizon to evaluate whether a mound stage is present at this level.

Stratigraphy uncovered in core 7 revealed the possibility that mound D was constructed in as many as four stages or perhaps as little as two. The last two potential mound stages, three and four, were fairly minor and within the first $25 \mathrm{cmbs}$, and therefore, the possibility remains the susceptibility peaks seen in core 7 (Figure 13) for the third and fourth surfaces may instead represent slope wash of anthropogenic summit sediments. Mound stages one and two were visually identified in core 7 through the pedology; however, they did not both have strong signals in the down-hole instrument. The horizon identified as the second mound surface exhibited a strong susceptibility signal, which corroborates our sediment analysis; however, the similarly identified first mound stage does not have a strong susceptibility signal. Furthermore, the pre-mound surface, which was the natural ground surface on which the mound was built, did not have a strong susceptibility signal even though visually and texturally it appeared to 
be a well-defined anthropic horizon. The absence of a strong signal at the buried pre-mound surface may be related to the absence of magnetic iron oxides, although this would be unexpected in a silty clay loam A horizon.

Consequently, we found magnetic susceptibility to be a useful technology for evaluating, corroborating, and sometimes confounding in-field characterizations of sediments. In mound $\mathrm{A}$, the instrument was incredibly useful at validating our sediment identifications. However, at times, like on mounds $C$ and $D$, we found that the instrument raised more questions by identifying undifferentiated sediments as strongly magnetic or by having weakly magnetic readings at horizons that appeared anthropogenic in the pedology. These ambivalent and conflicting situations could likely be remedied by excavating multiple cores much closer together and by taking down-hole magnetic susceptibility readings in each bore hole, and therefore, the possibilities of correlating stratigraphy are much greater and the likelihood of instrument errors and idiosyncratic soil horizons far less. Our work was, however, successful at answering some questions we identified prior to beginning our fieldwork.

Where Was the River and Was It an Active Channel When the Site Was Occupied? Data from the cores revealed that Fisk's channel 11 appears to have been active for at least some period of occupation of the Carson mounds site. It is conceivable that the river was not active when the site was first occupied, but that it avulsed into what we call channel 11 as people were living on the landscape. Repeated flooding, or one massive flood event, may have forced people off the land for some time before they returned to continue building mounds and living at the site. It is possible that the many small house mounds shown on Holmes' map were built as a means of adapting to the frequent inundation of the landscape or as purposeful eminences where height had symbolic advantages, but other interpretations are also plausible. At the Hollywood site in the north Mississippi Delta, smaller earthen mounds were specifically built as substructures for domestic houses [86]. Some of these mounds could represent burial mounds or ossuaries. More likely, they represent accumulations of earth and debris during long periods of settlement and activity in domestic structures, perhaps similar to the Mississippian house mounds at the Shiloh site in Tennessee [121].

Are Sediment Cores Enough to Determine if Carson Was One Site or a Palimpsest of Many? It is unclear if Carson was one cohesive site and/or political entity lasting roughly over $600-700$ years $[69,77]$. We do know that William Henry Holmes and Cyrus Thomas's [68] assistants traveled Mississippi's Yazoo Basin in 1882 and 1883 before centralized management of levee and dyke construction (National Anthropological Archives MS 2400). River channelization by the United States Army Corps of Engineers significantly altered this region of the Yazoo Basin, and consequently, the landscape that Holmes witnessed was much closer to the prehistoric Native American landscape than the modern Yazoo landscape. That they called Carson one archaeological site should not be taken for granted. There is the distinct possibility that by the time the site was described by twentieth-century archaeologists, the landscape had changed dramatically due to erosion, agriculture, and alluvial processes, and that it no longer resembled the landscape at the time of Mississippian occupation or when Holmes viewed it. It is for this reason, then, that we utilize geoarchaeological methods to study the prehistoric landscape and to try and discover the nature of community and leadership at the Carson mounds site. Furthermore, continued analysis of surface-collected ceramics and the recovery of material culture from stratigraphically secure contexts will build on the work of Connaway, Brown [69], and Brent Lansdell [98] and facilitate chronological and spatial ordering at the Carson site.

Recent fieldwork at Carson has presented a preliminary evaluation of the geomorphology of the Carson mounds landscape. Research revealed that a nearby Mississippi River channel, perhaps Fisk's channel 11, was actively depositing sediments at the site while it was occupied and that a largescale avulsion from the channel likely resulted in the crevasse ridge under the mounds. Let us consider these data in the paradigm of historical ecology, a perspective in which humans have net effects on their environment, but they are not driven by intangible parameters to destroy or preserve their environment. In the rapidly changing floodplain environments of the Yazoo Basin, it is evident the indigenous residents witnessed the movement of the Mississippi River, the formation of crevasses, levees, and lakes, and also the destruction of their villages and monuments through flooding. People likely and frequently witnessed natural geomorphic processes in action; in the case of Carson, it appears a large-scale crevasse created a long and linear ridge that was subsequently settled on sometime after $1000 \mathrm{AD}$. In this natural landscape they created permanent alterations through the construction of large earthen monuments, small earthen mounds, and an earthen embankment. Remembering Malinowski's quote [1, page 37] from the beginning of this essay, it is important to note how an artificial or cultural landscape was created on a newly formed natural landform. He noted that culture must be permanently reproduced and maintained, and therefore, we think it is of the utmost relevance that a rapidly-formed crevasse was chosen as the site for the Carson site, a prehistoric village once marked by over 86 earthen mounds. The building of earthen mounds itself was a form of culture, a recreation and solidification of identity that has an antiquity of thousands of years in the LMV; recreating mounds at the Carson site at that specific landform was no coincidence. We might even suggest that in a rapidly changing, geomorphic floodplain, the only landforms of long-lasting permanence were the large, artificial earthen mounds built by the Indians of the LMV (During the massive and devastating 1927 floods of the Mississippi River, the only eminences above water in the Southern Yazoo Basin were the earthen mounds built by the region's indigenous residents and the modern river levees constructed in the 19th and 20th centuries [122]). Given the crevasse ridge was likely to have been far above the flood-zone, locating the earthen mounds on the crevasse landform might presuppose Native knowledge of floodplain dynamics, as well as have served 
to mark an anthropogenic landscape and to permanently demarcate a space as both natural and cultural. Thus, in this context, it is possible to see from Malinowski's perspective how the environment is nothing less than culture itself.

\section{Acknowledgments}

The authors gratefully recognize the following for their assistance with fieldwork and research-the Department of Anthropology at Tulane University, the Center for Archaeology at Tulane University, the New Orleans Center for the Study of the Gulf South at Tulane University, the University of Queensland, the Mississippi Department of Archives and History, Pamela Lieb and David Abbott, the Natural Resources Conservation Service, the Archaeological Conservancy, Jessica Crawford, George Lowry, Coastal Environments, Inc., the University of Mississippi and Jay K. Johnson, George Riser, Ian W. Brown, Haley Holt, Rachel Horowitz, Erlend Johnson, David Chatelain, Jessica Wheeler, and Bryan Haley. Finally, for all of his immeasurable support and advice, the author thanks his adviser, Christopher R. Rodning.

\section{References}

[1] B. Malinowski, A Scientific Theory of Culture and Other Essays, University of North Carolina Press, Chapel Hill, NC, USA, 1944.

[2] A. L. Young, "Sad song in the Delta: the potential for historical archaeology in the I-69 corridor," in Times River: Archaeological Syntheses from the Lower Mississippi River Valley, J. Rafferty and E. Peacock, Eds., pp. 395-425, The University of Alabama Press, Tuscaloosa, Ala, USA, 2008.

[3] E. Peacock, "Paleoenvironmental modeling in the Central and lower Mississippi river valley: past and future approaches," in Times River: Archaeological Syntheses from the Lower Mississippi River Alluvial Valley, J. Rafferty and E. Peacock, Eds., pp. 69-98, The University of Alabama Press, Tuscaloosa, Ala, USA, 2008.

[4] D. H. Usner, Settlers and Slaves in a Frontier Exchange Economy: The Lower Mississippi Valley before 1783, University of North Carolina Press, Chapel Hill, NC, USA, 1992.

[5] J. C. Willis, Forgotten Time: The Yazoo-Mississippi Delta after the Civil War, University Press of Virginia, London, UK, 2000.

[6] R. S. Weddle, "Soto's problems of orientation: maps, navigation, and instruments in the Florida expedition," in The Hernando de Soto Expedition: History, Historiography, and "Discovery" in the Southeast, P. Galloway, Ed., pp. 219-233, University of Nebraska Press, London, UK, 1997.

[7] C. C. Hudson, Knights of Spain, Warriors of the Sun: Hernando de Soto and the South's Ancient Chiefdoms, University of Georgia Press, London, UK, 1997.

[8] W. Balée, Advances in Historical Ecology, Columbia University Press, New York, NY, USA, 1998.

[9] C. Crumley, Historical Ecology: Cultural Knowledge and Changing Landscapes, School of American Research, Santa Fe, NM, USA, 1994.

[10] T. R. Kidder, "Perspectives on the geoarchaeology of the Lower Mississippi Valley," Engineering Geology, vol. 45, no. 1-4, pp. 305-323, 1996.

[11] C. C. Mann, 1491: New Revelations of the Americas before Columbus, Vintage Books, 2006.
[12] J. P. Brain, Winterville: Late Prehistoric Culture Contact in the Lower Mississippi Valley. Lower Mississippi Survey of Harvard University. Submitted to Mississippi Department of Archives and History, Archaeological Report No. 23. Jackson, Mississippi, 1989.

[13] P. Phillips, Archaeological Survey in the Lower Yazoo Basin, Mississippi, 1949-1955, Papers of the Peabody Museum of Archaeology and Ethnology 60, Harvard University, Cambridge, Mass, USA, 1970.

[14] P. Phillips, J. A. Ford, and J. B. Griffin, Archaeological Survey in the Lower Mississippi Alluvial Valley, 1940-1947, Originally printed as Papers of the Peabody Museum of Archaeology and Ethnology, Vol. 25 Harvard University, Cambridge, Mass, USA, University of Alabama Press, Tuscaloosa, Ala, USA, 2003.

[15] S. Williams and J. P. Brain, Excavations at the Lake George Site, Yazoo County, Mississippi,1958-1960, vol. 74 of Papers of the Peabody Museum of Archaeology and Erhnology, Harvard University, 1983.

[16] C. S. Peebles and S. M. Kus, "Some archaeological correlates of ranked societies," American Antiquity, vol. 42, no. 3, pp. 421-448, 1977.

[17] V. Steponaitis, Ceramics, Chronology, and Community Patterns: An Archaeological Study at Moundville, Academic Press, New York, NY, USA, 1983.

[18] P. D. Welch, Moundville's Economy, University of Alabama Press, Tuscaloosa, Ala, USA, 1991.

[19] A. King, Southeastern Ceremonial Complex: Chronology, Content, Context, University of Alabama Press, Tuscaloosa, Ala, USA, 2007.

[20] V. J. Knight, "Moundville as a diagrammatic ceremonial center," in Archaeology of the Moundville Chiefdom, V. J. Knight Jr. and V. P. Steponaitis, Eds., pp. 44-62, Smithsonian Institution Press, Washington, DC, USA, 1998.

[21] F. K. Reill and y and J. Garber, Ancient Objects and Sacred Realms: Interpretations of Mississippian Iconography, vol. 2, University of Texas Press, Austin, Tex, USA, 2007.

[22] G. D. Wilson, The Archaeology of Everyday Life at Early Moundville, University of Alabama Press, Tuscaloosa, Ala, USA, 2007.

[23] J. P. Brain, "Late prehistoric settlement patterning in the Yazoo Basin and Natchez Bluffs Regions of the Lower Mississippi Valley," in Mississippian Settlement Patterns, B. Smith, Ed., pp. 331-368, Academic Press, New York, NY, USA, 1978.

[24] P. K. Galloway and J. B. Griffin, Eds., The Southeastern Ceremonial Complex: Artifacts and Analysis, University of Nebraska Press, 1989.

[25] V. J. Knight, "Farewell to the southeastern ceremonial complex," Southeastern Archaeology, vol. 25, no. 1, pp. 1-5, 2006.

[26] P. Livingood, "Recent discussions in late prehistoric Southern Archaeology," Native South, vol. 1, pp. 1-26, 2008.

[27] A. J. Waring and P. Holder, "A prehistoric ceremonial complex in the Southeastern United States," American Antiquity, vol. 47, no. 1, pp. 1-34, 1945.

[28] R. B. Clay, "Tactics, strategy, and operations: the Mississippian system responds to its environment," Midcontinental Journal of Archaeology, vol. 1, no. 2, pp. 137-162, 1976.

[29] B. D. Smith, Mississippian Settlement Patterns, Academic Press, New York, NY, USA, 1978.

[30] J. H. Blitz, "New perspectives in Mississippian archaeology," Journal of Archaeological Research, vol. 18, no. 1, pp. 1-39, 2010. 
[31] C. R. Cobb, "Specialization, exchange, and power in smallscale societies and chiefdoms," Research in Economic Anthropology, vol. 17, pp. 251-294, 1996.

[32] J. Z. Holt, "Rethinking the ramey state: was cahokia the center of a theater state?" American Antiquity, vol. 74, no. 2, pp. 231-254, 2009.

[33] T. R. Pauketat, Chiefdoms and Other Archaeological Delusions, Altamira Press, Lanham, Md, USA, 2007.

[34] M. Sahlins and E. R. Service, Evolution and Culture, University of Michigan Press, Ann Arbor, Mich, USA, 1960.

[35] F. A. Hassan, "Human agency, climate change, and culture: an archaeological perspective," in Anthropology and Climate Change: From Encounters to Actions, S. A. Crate and M. Nuttall, Eds., Left Coast Press, Calif, USA, 2009.

[36] M. J. Heckenberger, The Ecology of Power: Culture, Place, and Personhood in the Southern Amazon, A.D. 1000-2000, Routledge Press, New York, NY, USA, 2005.

[37] T. R. Kidder, "Plazas as architecture: an example from the Raffman site, Northeast Louisiana," American Antiquity, vol. 69, no. 3, pp. 514-532, 2004.

[38] S. Schroeder, "Power and place: agency, ecology, and history in the American Bottom, Illinois," Antiquity, vol. 78, no. 302, pp. 812-827, 2004.

[39] C. Erickson, "Amazonia: the historical ecology of a domesticated landscape," in Handbook of South American Archaeology, H. Silverman and W. H. Isbell, Eds., pp. 157-183, Springer, New York, NY, USA, 2008.

[40] J. R. Flenley, “Man's impact on the vegetation of Southeast Asia: the pollen evidence. Recent advances in indo-pacific prehistory," in Proceedings of the International Symposium Held at Poona, New Delhi, India, 1978.

[41] P. Leveau, T. Frédéric, W. Kevin, and B. Graeme, Eds., Environmental Reconstruction in Mediterranean Landscape Archaeology, Oxbow Books, Oxford, UK, 1999.

[42] T. C. Rick, The Archaeology of Historical Ecology of Late Holocene San Miguel Island. Perspectives in California Archaeology, vol. 8, Cotsen Institute of Archaeology, Los Angeles, Calif, USA, 2007.

[43] T. J. Wilkinson, Archaeological Landscapes of the Near East, The University of Arizona Press, Board of Regents, 2003.

[44] P. A. Delcourt, H. R. Delcourt, R. C. Brister, and L. E. Lackey, "Quaternary vegetation history of the Mississippi embayment," Quaternary Research, vol. 13, no. 1, pp. 111-132, 1980.

[45] P. A. Delcourt, H. R. Delcourt, and R. T. Saucier, "Late quaternary vegetation dynamics in the Central Mississippi Valley," in Arkansas Archaeology: Essays in Honor of Dan and Phyllis Morse, R. C. Mainfort and M. Jeter, Eds., The University of Arkansas Press, Fayetteville, Ark, USA, 1999.

[46] P. A. Delcourt and H. R. Delcourt, Prehistoric Native Americans and Ecological Change: Human Ecosystems in Eastern North America since the Pleistocene, Cambridge University Press, Cambridge, UK, 2004.

[47] R. L. Jolley, "Mississippian adaptations to the middle cumberland drainage of Central Tennessee," Midcontinental Journal of Archaeology, vol. 8, no. 1, pp. 73-90, 1983.

[48] J. W. Lallo and J. C. Rose, "Patterns of stress, disease and mortality in two prehistoric populations from North America," Journal of Human Evolution, vol. 8, no. 3, pp. 323-335, 1979.

[49] R. T. Saucier, "Current thinking on riverine processes and geologic history as related to human settlement in the southeast," Geoscience and Man, vol. 22, pp. 7-18, 1981.

[50] R. T. Saucier, "Towasahgy state historic site and its physical environment," The Missouri Archaeologist, vol. 51, pp. 72-91, 1990.
[51] J. Steward, Theory of Culture Change: The Methodology of Multilinear Evolution, University of Illinois Press, UrbanaChampaign, Ill, USA, 1955.

[52] J. E. Hammett, "The shapes of adaptation: historical ecology of anthropogenic landscapes in the southeastern United States," Landscape Ecology, vol. 7, no. 2, pp. 121-135, 1992.

[53] J. E. Hammett, "Ethnohistory of aboriginal landscapes in the Southeastern United States," Southern Indian Studies, vol. 41, pp. 1-50, 1992.

[54] T. R. Kidder and R. T. Saucier, "Archaeological and geological evidence for protohistoric water management in Northeast Louisiana," Geoarchaeology, vol. 6, no. 4, pp. 307-335, 1991.

[55] K. F. Anschuetz, R. H. Wilshausen, and C. L. Scheick, "An archaeology of landscapes: perspectives and directions," Journal of Archaeological Research, vol. 9, no. 2, pp. 157-198, 2001.

[56] L. J. Arco, K. A. Adelsberger, L. Y. Hung, and T. R. Kidder, "Alluvial geoarchaeology of a Middle Archaic mound complex in the lower Mississippi valley, U.S.A," Geoarchaeology, vol. 21, no. 6, pp. 591-614, 2006.

[57] R. A. Dalan, "Construction of Mississippian Cahokia," in Cahokia Domination and Ideology in the Mississippian World, T. R. Pauketat and T. E. Emerson, Eds., pp. 89-102, University of Nebraska Press, Lincoln, Neb, USA, 1997.

[58] R. A. Dalan, G. R. Holley, W. I. Woods, H. W. Watters, and J. A. Koepke, Envisioning Cahokia: A Landscape Perspective, Northern Illinois University Press, DeKalb, Ill, USA, 2003.

[59] G. R. Holley, R. A. Dalan, and P. A. Smith, "Investigations in the Cahokia Site Grand Plaza," American Antiquity, vol. 58, no. 2, pp. 306-319, 1993.

[60] G. Children and G. Nash, "The language of landscape," in Semiotics of Landscape: Archaeology of Mind, British Archaeological Report Series, pp. 1-4, Archaeo Press, Oxford, UK, 1997.

[61] T. R. Pauketat, Ancient Cahokia and the Mississippians, Cambridge University Press, Cambridge, UK, 2004.

[62] J. H. Blitz, Moundville, The University of Alabama Press, Tuscaloosa, Ala, USA, 2008.

[63] V. J. Knight and V. P. Steponaitis, Archaeology of the Moundville Chiefdom, Smithsonian Institution press, Washington, DC, USA, 1998.

[64] C. R. Cobb and A. King, "Re-inventing mississippian tradition at Etowah, Georgia," Journal of Archaeological Method and Theory, vol. 12, no. 3, pp. 167-193, 2005.

[65] A. King, "De Soto's Itaba and the nature of sixteenth century paramount chiefdoms," Southeastern Archaeology, vol. 18, no. 2, pp. 110-123, 1999.

[66] A. King, "Long-term histories of Mississippian centers: the developmental sequence of Etowah and its comparison to Moundville and Cahokia," Southeastern Archaeology, vol. 20, no. 1, pp. 1-17, 2001.

[67] A. King, "Over a century of explorations at Etowah," Journal of Archaeological Research, vol. 11, no. 4, pp. 279-306, 2003.

[68] C. Thomas, "Report on the Mound Explorations of the Bureau of Ethnology for the Years 1890-1891," 12th Annual Report to the Bureau of American Ethnology, Smithsonian Institution, Washington, DC, USA, 1894.

[69] I. W. Brown, "An archaeological survey of Mississippi period sites in Coahoma County, Mississippi," Final Report, Cottonlandia Museum, Greenwood, Mississippi, and Lower Mississippi Survey, Peabody Museum, Harvard University, Cambridge, Mass, USA, 1978.

[70] M. A. Canuto and J. Yaeger, The Archaeology of Communities: A New World Perspective, Routledge Press, New York, NY, USA, 2000 
[71] M. Elliott, Human occupation and landscape change in the Malpaso Valley, Zacatecas, Mexico [PhD dissertation], UMI, Arizona State University, Ann Arbor, Mich, USA, 1997.

[72] H. N. Fisk, "Geological Investigations of the Alluvial Valley of the Lower Mississippi River," Mississippi River Commission, Vicksburg, Miss, USA, 1944.

[73] R. T. Saucier, Geomorphology and Quaternary Geology of the Lower Mississippi Valley, vol. 2, Army Engineer Waterways Experiment Station, Vicksburg, Miss, USA, 1994.

[74] J. P. Brain, "The Lower Mississippi Valley in North American Prehistory," National Park Service and Arkansas Archeological Survey, 1971.

[75] J. P. Brain, "The De Soto Entrada in the Lower Mississippi Valley," Mississippi Archaeology, vol. 19, no. 2, pp. 48-58, 1984.

[76] S. O. Brookes and C. Taylor, "Tchula period ceramics in the upper sunflower region," in The Tchula Period in the MidSouth and Lower Mississippi Valley, D. H. Dye and R. C. Brister, Eds., Archaeological Report No. 17, pp. 23-37, Mississippi Department of Archives and History, Jackson, Miss, USA, 1986.

[77] C. Brown, Archaeology of Mississippi, University Press of Mississippi, Jackson, Miss, USA, 1992.

[78] I. W. Brown, Early 18th Century French-Indian Culture Contact in the Yazoo Bluffs Region [Ph.D. dissertation], Brown University, Rhode Island, NJ, USA, 1980.

[79] J. M. Connaway, "The Denton Site: A Middle Archaic Occupation in the Northern Yazoo Basin, Mississippi," Archaeological Report No. 4, Mississippi Department of Archives and History, Jackson, Miss, USA, 1977.

[80] J. M. Connaway, "Archaeological Investigations in Mississippi, 1969-1977," Archaeological Report No. 6. Mississippi Department of Archives and History, Jackson, Miss, USA, 1981.

[81] J. M. Connaway, “The Wilsford Site (22CO516), Coahoma County, Mississippi: A Late Mississippi Period Settlement in the Northern Yazoo Basin of Mississippi," Archaeological Report No. 14. Mississippi Department of Archives and History, Jackson, Miss, USA, 1984.

[82] J. M. Connaway and S. O. McGahey, "Archaeological Excavations at the Boyd Site, Tunica County, Mississippi," Tech. Rep. 1, Mississippi Department of Archives and History, Jackson, Miss, USA, 1971.

[83] J. M. Connaway and S. McGahey, "Archaeological reconnaissance: survey of remnant braided stream surfaces in the western central Yazoo Basin," Mississippi Archaeology, vol. 31, no. 2, pp. 23-50, 1996.

[84] J. M. Connaway, S. O. McGahey, and C. H. Webb, "Teoc Creek: A Poverty Point Site in Carroll County, Mississippi," Archaeological Report 3. Mississippi Department of Archives and History, Jackson, Miss, USA, 1977.

[85] P. D. Edwards, An analysis of late prehistoric ceramics from the Hollywood Site (22TU500) in Tunica County, Mississippi [Master's thesis], Department of Sociology and Anthropology, University of Mississippi, 2003.

[86] B. Haley, Airborne remote sensing, image processing, and multisensor data fusion at the Hollywood Site, a large late Mississippian Mound Center [M.S. thesis], Department of Sociology and Anthropology, University of Mississippi, 2002.

[87] J. K. Johnson, "Poverty point period social organization in the Yazoo Basin, Mississippi: a preliminary examination," in Caddoan and Poverty Point Archaeology: Essays in Honor of Clarence Hungerford Webb, J. L. Gibson, Ed., Louisiana Archaeology 6, pp. 251-281, 1980.
[88] J. K. Johnson, "Cahokia core technology in Mississippi: the view from the South," in The Organization of Core Technology, J. K. Johnson and C. A. Morrow, Eds., pp. 187-206, Westview Press, London, UK, 1986.

[89] J. K. Johnson, "Poverty point period chrystal drill bits, microliths, and social organization in the Yazoo Basin, Mississippi," Southeastern Archaeology, vol. 12, pp. 59-64, 1993.

[90] J. K. Johnson, G. M. Aleo, R. T. Stuart, and J. Sullivan, "Excavations at the Batesville Mounds: A Woodland Period Platform Mound Complex in Northwest Mississippi," Mississippi Department of Archives and History, Archaeological Report No. 32, Jackson, Miss, USA, 1996.

[91] G. R. Lehman, “The Jaketown Site: Surface Collections from a Poverty Point Regional Center in the Yazoo Basin, Mississippi," Mississippi Department of Archives and History, Archaeological Report No. 9, Jackson, Miss, USA, 1982.

[92] J. N. Peukert, Ground penetrating radar at Hollywood, 22 TU500 [M.S. thesis], Department of Sociology and Anthropology, University of Mississippi, 2002.

[93] C. B. Moore, "The Lower Mississippi valley expeditions of Clarence Bloomfield Moore," in Classics in Southeastern Archaeology, F. Dan and P. A. Morse, Eds., University of Alabama Press, Tuscaloosa, Ala, USA, 1998.

[94] D. T. Morgan, "The Mississippi De Soto Trail-Mapping Project," Mississippi Department of Archives and History, Archaeological Report No. 26, Jackson, Miss, USA, 1996.

[95] M. D. Reynolds, Magnetic Remote Sensing and Ground Truth: Some Examples from the Hollywood Site [M.S. thesis], Department of Sociology and Anthropology, University of Mississippi, Tunica County, Miss, USA, 2002.

[96] A. Toth, Early Marksville Phases in the Lower Mississippi Valley: A Study of Culture Contact Dynamics, Mississippi Department of Archives and History, Jackson, Miss, USA, 1988.

[97] L. E. Downs, Plaquemine culture structures in the Natchez Bluffs: architectural grammar at the mound 3 summit locale, the Anna site, Adams County, Mississippi [M. S. thesis], Department of Anthropology, University of Alabama, Tuscaloosa, Ala, USA, 2004.

[98] B. Lansdell, A chronological assessment of the Carson mound group, Stovall, Mississippi [M.S. thesis], Department of Anthropology and Sociology, University of Mississippi, 2009.

[99] C. T. Lewis III, Excavations at the Chittoloosa Site (22WR631): Exploration of a Late Prehistoric Frontier in the Lower Big Black Region of West Central Mississippi [Ph.D. thesis], Department of Anthropology, University of Alabama, Tuscaloosa, Ala, USA, 2008.

[100] J. K. Johnson, "Cyclic changes in the structural organizations of Mississippian mound sites in the Yazoo Basin," in Proceedings of the 20th Annual Visiting Scholar Conference, Center for Archaeological Investigations, Southern Illinois University, Carbondale, Ill, USA, 2003.

[101] E. L. Stevens, The making of a monument: investigating mound stratigraphy in the Yazoo Basin [M.S. thesis], Department of Anthropology and Sociology, University of Mississippi, Oxford, UK, 2006.

[102] G. D. Strickland, Multidimensional visual testing of a mississippian mound [M.S. thesis], Department of Sociology and Anthropology, University of Mississippi, 2009.

[103] T. R. Kidder, "Climate change and the Archaic to Woodland transition (3000-2500 cal B.P.) in the Mississippi River basin," American Antiquity, vol. 71, no. 2, pp. 195-231, 2006.

[104] E. Peacock and J. Gerber, "Using land snails and freshwater mussels to chart human transformation of the landscape: an example from Northeast Mississippi, USA," in Case Studies 
in Environmental Archaeology, E. J. Reitz, C. M. Scarry, and S. J. Schudder, Eds., pp. 123-141, Springer Science Business Media, London, UK, 2nd edition, 2008.

[105] V. J. Knight, J. A. Brown, and G. E. Lankford, "On the subject matter of southeastern ceremonial complex art," Southeastern Archaeology, vol. 20, no. 2, pp. 129-141, 2001.

[106] I. W. Brown, "Bottle Creek: A Pensacola Culture Site in South Alabama," The University of Alabama Press, Tuscaloosa, Ala, USA, 2003.

[107] P. Phillips and J. A. Brown, Pre-Columbian Shell Engravings from the Craig Mound at Spiro Oklahoma, Peabody Museum of Archaeology and Ethnology, Harvard University, Cambridge, Mass, USA, 1982.

[108] J. P. Brain, A. Toth, and A. Rodriguez-Buckingham, "Ethnohistoric archaeology and the De Soto Entrada into the Lower Mississippi Valley," in Proceedings of the Conference on Historic Site, vol. 7, paper 1772, pp. 223-298, 1974.

[109] R. Thompson and F. Oldfield, Environmental Magnetism, George Allen and Unwin Press, Wales, UK, 1986.

[110] R. A. Dalan, "A magnetic susceptibility logger for archaeological application," Geoarchaeology, vol. 16, no. 3, pp. 263-273, 2001.

[111] R. A. Dalan, "A review of the role of magnetic susceptibility in archaeogeophysical studies in the USA: recent developments and prospects," Archaeological Prospection, vol. 15, no. 1, pp. 1-31, 2008.

[112] G. Prentice, Ancient Indian Architecture of the Lower Mississippi Delta Region: A Study of Earthworks, Southeastern Archaeological Center, Tallahassee, Fla, USA, 2000.

[113] R. T. Saucier, "A contemporary appraisal of some key Fiskian concepts with emphasis on Holocene meander belt formation and morphology," Engineering Geology, vol. 45, no. 1-4, pp. 67-86, 1996.

[114] W. J. Autin, S. F. Burns, B. J. Miller, R. T. Saucier, and J. I. Snead, "Quaternary geology of the lower Mississippi valley," in The Geology of North America, vol. 2, pp. 547-582, Quaternary Nonglacial Geology: Coterminous US, 1991.

[115] K. M. Lowe, "Evaluating paleochannels using interdisciplinary methods in the Yazoo Basin of Northwest Mississippi," in Proceedings of the 34th Conference on Digital Discovery: Exploring New Frontiers in Human Heritage. Computer Applications and Quantitative Methods in Archaeology, Fargo, ND, USA, 2006.

[116] A. S. Fogel, Investigating a Mississippian mound top structure utilizing archaeogeophysics and archaeology: a three-dimensional application of down-hole magnetic susceptibility technology [M.S. thesis], Department of Sociology and Anthropology, University of Mississippi, 2005.

[117] J. K. Stein, "Coring archaeological sites," American Antiquity, vol. 51, no. 3, pp. 505-527, 1986.

[118] J. H. Blitz and P. Livingood, "Sociopolitical implications of Mississippian mound volume," American Antiquity, vol. 69, no. 2, pp. 291-301, 2004.

[119] N. C. Brady, The Nature and Properties of Soils, Macmillan Publishing Company, New York, NY, USA, 1990.

[120] R. B. Lewis, Mississippian Exploitative Strategies; a southeast Missouri Example, Research Series 11, Missouri Archaeological Society, 1974.

[121] P. D. Welch, Archaeology at Shiloh Indian Mounds, 1899-1999, University of Alabama Press, Tuscaloosa, Ala, USA, 2006.

[122] J. M. Barry, Rising Tide: The Great Mississippi Flood of 1927 and How it Changed America, Simon and Schuster, New York, NY, USA, 1998. 


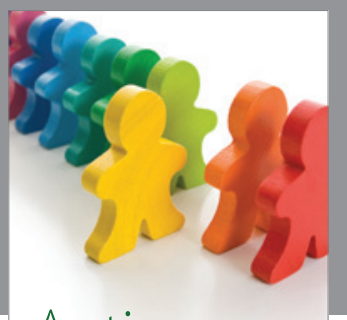

Autism

Research and Treatment
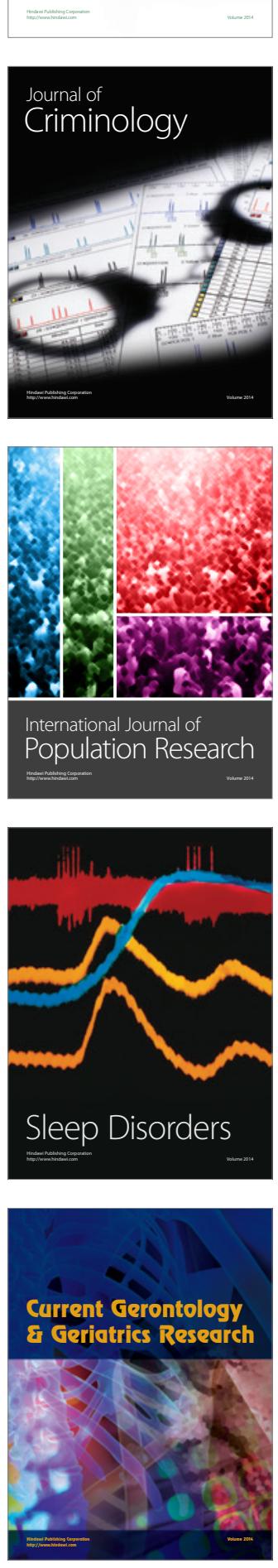
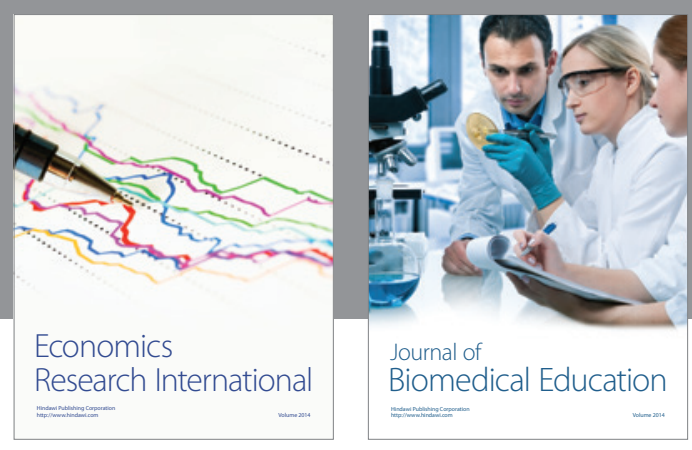

Journal of

Biomedical Education

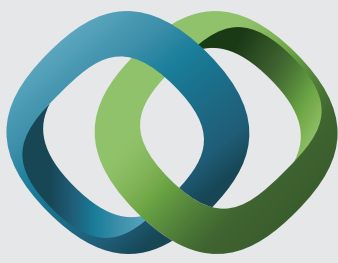

\section{Hindawi}

Submit your manuscripts at

http://www.hindawi.com
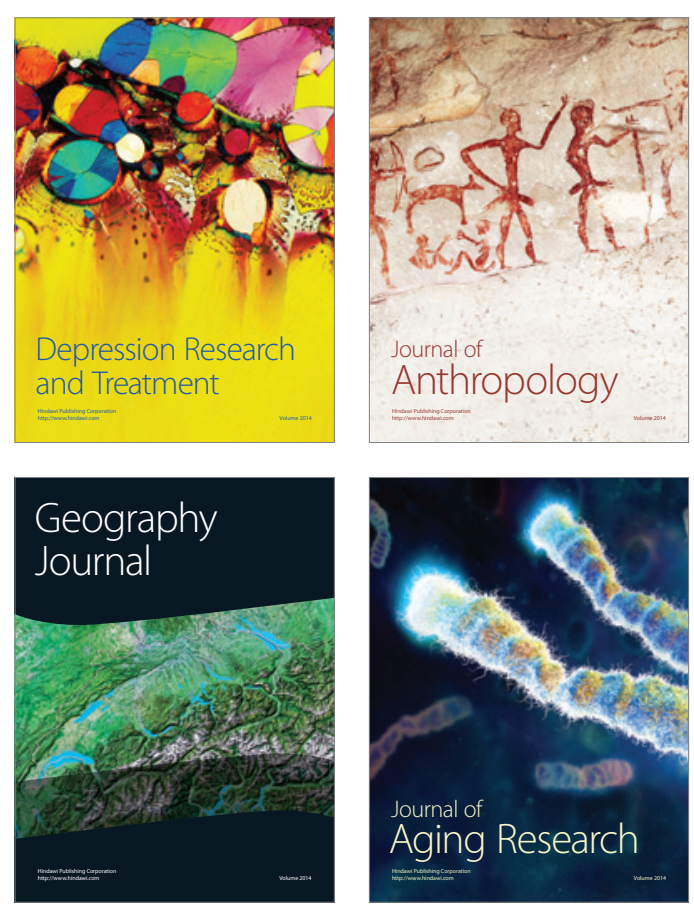

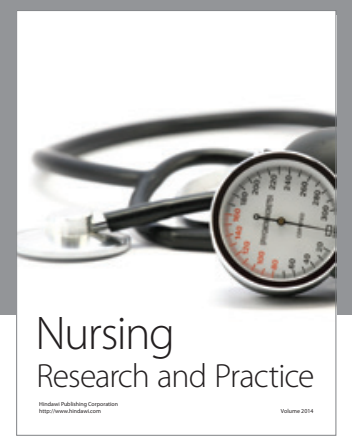

Nursing

Research and Practice

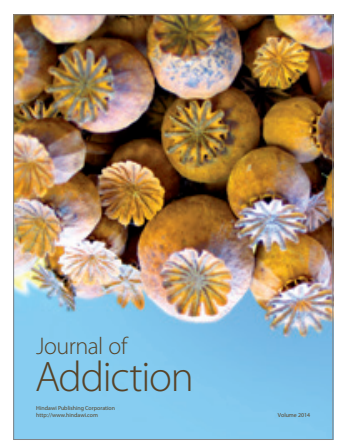

Child Development

Research

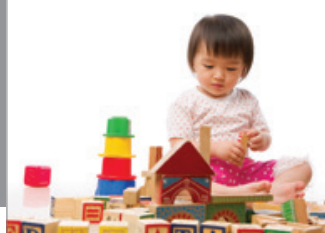

迥
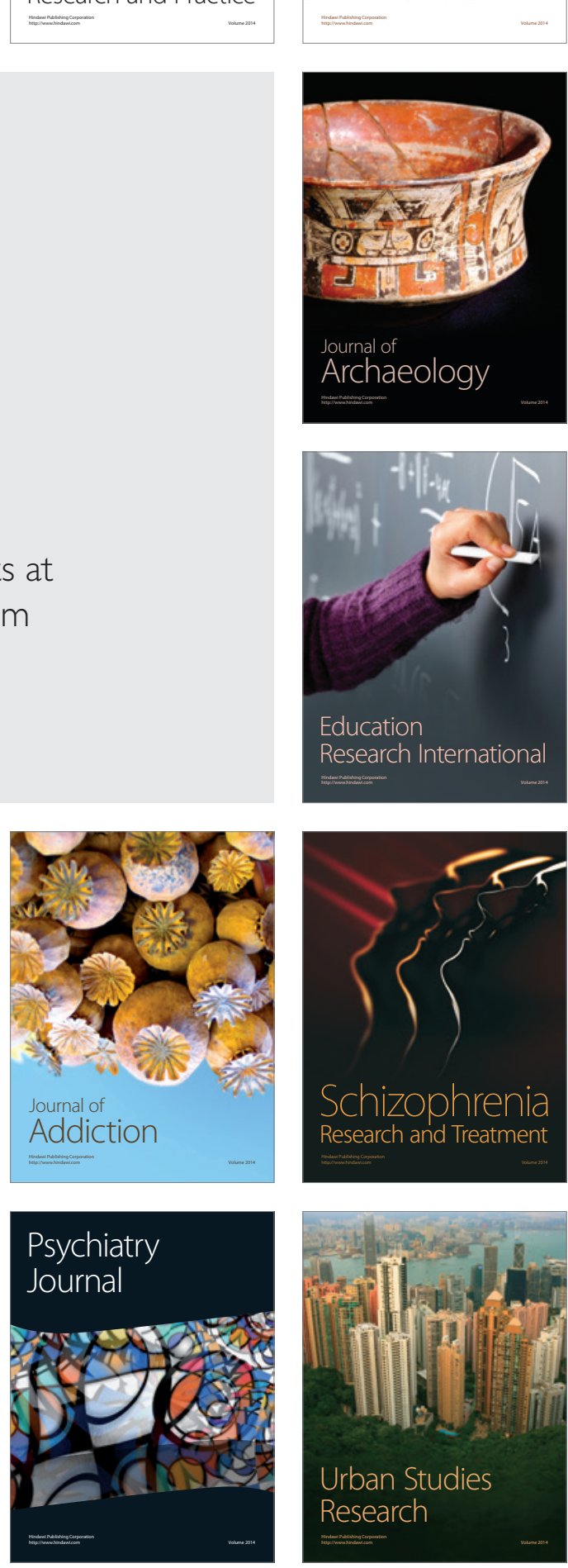